\title{
Immunogenicity of clinically relevant SARS-CoV-2 vaccines in non-human primates and humans
}

\author{
P. J. Klasse ${ }^{1, *}$, Douglas F. Nixon ${ }^{2, *}$, John P. Moore ${ }^{1, \dagger}$ \\ ${ }^{1}$ Department of Microbiology and Immunology. ${ }^{2}$ Division of Infectious Diseases, Department of Medicine, Weill Cornell Medical College, New York, NY 10065 \\ ${ }^{\dagger}$ Corresponding author. Email: jpm2003@med.cornell.edu
}

Multiple preventive vaccines are being developed to counter the COVID-19 pandemic. The leading candidates have now been evaluated in non-human primates (NHPs) and human Phase 1 and/or Phase 2 clinical trials. Several vaccines have already advanced into Phase 3 efficacy trials, while others will do so before the end of 2020. Here, we summarize what is known of the antibody and T-cell immunogenicity of these vaccines in NHPs and humans. To the extent possible, we compare how the vaccines have performed, taking into account the use of different assays to assess immunogenicity and inconsistencies in how the resulting data are presented. We also review the outcome of SARS-CoV-2 challenge experiments in immunized macaques, while noting variations in the protocols used, including but not limited to the virus challenge doses. Press releases on the outcomes of vaccine efficacy trials are also summarized.

\section{Introduction}

The COVID-19 pandemic rages unabated and may continue to do so until there is a safe, effective and widely used protective vaccine. Multiple vaccines to prevent SARS-CoV-2 infection and/or COVID-19 disease are now progressing through pre-clinical testing and Phase 1/2a human trials, while some are already in Phase $2 b / 3$ efficacy trials in and outside the USA (https://www.who.int/who-documentsdetail/draft-landscape-of-covid-19-candidate-vaccines) (https://clinicaltrials.gov/ct2/results?recrs=\&cond=Covid19 \&term $=$ vaccine \&cntry $=\&$ state $=\& c i t y=\& d i s t=) \quad(1-32) \quad($ Table 1). Several of these mid- to late-stage vaccines are part of the US Government's Operation Warp Speed (OWS), which has been reviewed elsewhere (33-35). Multiple vaccine candidates produced in China are also well advanced in the evaluation and approval process $(1,2,12,14,15,22-24,29$, 30). Phase $1 / 2$ trial data on the Russian-made Sputnik V vaccine have now been published (28)

All the vaccines are either based solely on the viral Spike (S)-protein, which is administered by various methods including expression from non-replicating adenoviruses and nucleic acid vectors or as recombinant proteins, or are inactivated viruses that include the S-protein together with all other structural viral proteins (Table 1). The vaccines are all based on S-proteins containing D614, which was the dominant strain when they were designed. A variant virus with G614 in its S-protein has since emerged to dominance globally because of its greater transmissibility (36-38). However, this D614G change does not affect sensitivity to neutralization by sera from infected or vaccinated people, or to neutralizing MAbs (monoclonal antibodies), and therefore is not problematic for vaccine efficacy (36-38). Some of the more recent papers reviewed below include neutralization data using the G614 virus. All the Adenovirus, mRNA and DNA vaccine candidates listed in Table 1 involve full-length $S$ proteins; variants with truncations of the transmembrane region and/or the cytoplasmic tail were tested as comparators in two macaque studies $(4,6)$. The recombinant proteins from Novavax and Clover Biopharm. are based on full-length Sproteins $(9,10,12,21)$. Many S-protein constructs incorporate two proline substitutions in the S2 region (K986P and V987P) that stabilize the expressed trimer in the pre-fusion structure that is considered to be optimally immunogenic for the induction of NAbs, while minimizing non-NAb responses (39). The same method was used to stabilize the respiratory syncytial virus F-protein and improve its immunogenicity (40, 41). In one macaque study of Ad26 virus variants, the NAb response to the two-proline mutant S-protein was stronger than to other constructs that contained or lacked stabilizing changes, truncations or alternative leader sequences (4). A mouse immunogenicity experiment that also compared Ad26 virus variants led to a similar conclusion (42). Comparative experiments in mice led to the inclusion of the same double proline change (plus a furin cleavage site knockout) in the Sanofi Pasteur mRNA vaccine (13). Recombinant S-protein immunogens with the same combination of mutations provided the strongest protection against virus challenge in a mouse model, when compared with proteins that lacked these stabilizing changes (43). In a macaque comparison of DNA vaccines expressing various S-protein constructs, the authors reported that a soluble S-protein that contained the two proline substitutions together with a cleavage site knock- 
out and a trimerization domain (S.dTM.PP) was better than the corresponding truncated S-protein (S.dTM) at conferring protection from SARS-CoV-2 challenge (6).

Experimentation and precedent therefore support the use of stabilizing changes that maintain the SARS-CoV-2 S-protein trimer in its pre-fusion conformation. However, the Sprotein expressed in the AstraZeneca/Oxford University ChAdOx1 nCoV-19 vaccine is a wild type sequence that does not include any stabilizing changes $(3,16,17)$. The Sputnik V rAd5 and rAd26 adenovirus vectors express a full-length S-protein, but the published report does not mention whether stabilizing mutations were added (28). Similarly, it was not stated whether the S-protein in the CanSinoBio Ad5-nCoV vaccine was stabilized $(23,24)$. Whether the known or likely absence of stabilizing changes impacts the performance of these various adenovirus vaccines is not known.

The Pfizer/BioNTech BNT162b1 vaccine was based on the S-protein's receptor-binding domain (RBD), but its development was terminated after Phase $1 / 2$ trials, in favor of the BNT162b2 construct that expresses the complete, stabilized S-protein (Table 4) (11, 25-27). All the mRNA vaccines are encapsulated within liposomes of unpublished composition, which accounts for their thermal fragility and need for storage and shipment in freezers at various temperatures.

It is of considerable scientific and public interest to know the immunogenicity of the leading vaccines in absolute and, to the extent possible, comparative terms. Here, we have reviewed antibody and T-cell immune response data derived from published studies of vaccines that were tested in nonhuman primates (NHPs) and then progressed into human Phase $1 / 2$ trials, or that are in human trials without a prior NHP experiment (Tables 2-4). We have also evaluated macaque vaccine-challenge experiments, including how they were performed, as the outcomes are relevant to understanding the protective potential of SARS-CoV-2 vaccines (Table 3 ). The NHP experiments are described in references (1-13), the human trials in references (14-32).

The Chinese Government authorized the CanSino Ad5$\mathrm{nCoV}$ vaccine for use on military personnel in June 2020, presumably on the basis of the Phase $1 / 2$ trial data $(23,24)$. In August 2020, the Russian Government approved an Ad5 plus Ad26 adenovirus-vector vaccine, Gam-COVID-Vac (also referred to as Sputnik V), after minimal safety testing and with no evidence of protective efficacy, several weeks before Phase 1/2 trial data were published (28). Reservations have been expressed about the suitability of Ad5 vaccines for use in areas of high HIV-1 incidence, based on the risks of increased HIV1 acquisition (44). This concern would apply to both the Cansino Ad5-nCoV and the Gam-COVID-Vac vaccines (23, 24, 28 ). The approval processes that will be applied to the vaccines of the US Government-supported OWS program are outlined in brief elsewhere (33).
The immunogenicity of some of the $>150$ vaccine candidates now in pre-clinical development worldwide has been tested in small animals and, in some cases, NHPs. These reports are beyond the scope of this review, although we and others have summarized several previously $(34,35,45)$. Small-animal immunogenicity studies that directly relate to the vaccine candidates we review here are described in several of the papers on NHP experiments and human trials, and also in references $(42,46-50)$.

The first indications of vaccine efficacy emerged during November, 2020, with the appearance of 7 press releases. "Science by press release" is a far from ideal mechanism for the dissemination of important data, but is understandable in the context of the COVID-19 pandemic. The information in the press releases was generally quite limited, and of course the data were not peer reviewed. In some cases, more questions were raised than answers given. Nonetheless, it was clear that significant and meaningful levels of efficacy were being accomplished. None of the press releases reported significant safety problems. We summarize what is now known near the end of this review.

\section{Assessing antibody responses to vaccine candidates}

Antibodies induced by the S-protein based immunogens are generally measured in two ways. Immunoassays, usually but not always ELISAs, quantify antibody binding to the S-protein or fragments thereof, such as the RBD. Neutralization assays assess the abilities of neutralizing antibodies (NAbs) to inhibit SARS-CoV-2 infection of target cells $(51,52)$. The binding and neutralizing antibody assays both have value, and titers derived from them generally correlate reasonably well. However, neutralization assays quantify antibodies that block infection while ELISAs and other binding antibody assays also detect antibodies that lack such properties (nonneutralizing antibodies, or non-NAbs) (Figs. 1, 2, 3). Other assays are sometimes used, for example to detect antibodies that inhibit the binding of the S-protein or its RBD to a soluble form of the angiotensin-converting enzyme 2 (ACE2), which is the entry receptor for SARS-CoV-2. We restrict our discussion to binding antibodies and NAbs, with some exceptions. A repeated occurrence in the papers we summarize is the use of COVID-19 convalescent sera or plasma as comparators for vaccine-induced antibody responses. We have ignored all of these data sets. The serum/plasma panels differ among the various studies, and the range of antibody titers seen in COVID-19 patients can span a 5-log range and vary considerably also during convalescence $(34,35,51-55)$. Accordingly, we have not found the convalescent serum panels helpful when gauging the relative immunogenicity of the various vaccine candidates. There is a compelling need to now assemble and use a standard panel containing neutralizing monoclonal antibodies and/or validated convalescent plasma 
or purified IgG preparations for these comparisons $(34,35$, 51).

As we have noted previously, different research groups use different assays and measure antibody binding and virus neutralization differently, which greatly complicates comparisons of datasets (34). The different measurements made in the original papers are explained in Table 5 and Figs. 1 to 3 . How binding and neutralizing antibody titer and protection data derived from animal experiments that use different infectious doses of challenge virus can be related to each other has been modeled and discussed elsewhere $(51,52,56)$. The range of SARS-CoV-2 vaccine-induced antibody titers seen in groups of NHPs and humans generally exceeds 100-fold and can be as high as 1000-fold. As noted previously, the existence of such a wide range of responses has implications for the proportion of a population that a vaccine can protect (34). The titer spreads reported in the various primary papers are worth comparing from this perspective.

Antibody responses in the various studies are usually measured for only a short period after the final immunization or, in the case of some macaque experiments, after the virus challenge. The same constraint applies also to the T-cell data. In one study where evaluations were carried out for longer than is normal, rhesus macaques were immunized twice with the Pfizer/BioNTech BNT162b2 mRNA vaccine. The peak anti-S1 protein antibody titers then declined $\sim 5$-fold over a 28-day period while $\mathrm{NAb} \mathrm{RV} \mathrm{IC}_{50}$ titers also dropped $\sim 5$-fold in the high-dose $(100 \mu \mathrm{g})$ group (11). We estimate that the early-phase half-life of these antibody titers is only 1-2 weeks. The lack of knowledge of the longevity of SARS-CoV-2 vaccine-induced immune responses in humans is a substantial gap that will need filling.

In almost all of the papers we review, antibody responses are measured only in serum. There has been very little attention paid, to date, to mucosal immune responses, which seems unfortunate given how SARS-CoV-2 is transmitted and where it predominantly replicates. Accordingly, we cannot address mucosal immunity in this review, other than by noting that one recent preclinical study of a chimpanzee adenovirus vaccine (different from the AstraZeneca clinical candidate) in mice highlights how important inducing and characterizing mucosal immune responses might turn out to be (50).

In short, it is often difficult to inspect two different papers on vaccines $A$ and $B$ and conclude with certainty which one induces the superior immune response. Knowledge of how vaccines of different designs generally perform can help form judgements, but there must always be caveats.

\section{Assessing T-cell responses to vaccine candidates}

$\mathrm{T}$ cell responses to vaccine immunogens are generally measured by quantifying the amount of cytokine expressed by a $\mathrm{T}$ cell after specific antigenic stimulation from a peptide, protein or vector delivered antigen. The ELISPOT assay is most often used, or variants thereof, peripheral blood mononuclear cells (PBMC) being the commonest source for $\mathrm{T}$ cells. Interferon gamma secretion is the most commonly chosen cytokine output but other cytokines are sometimes also measured, as is the production of granzyme B. Cytokine flow cytometry (CFC) is often used as a read out, and there is generally a good correlation between ELISPOT and CFC assay results. An advantage of the CFC assay is that it can directly identify the phenotype of responding $\mathrm{T}$ cells, which requires depletions of cellular subsets in ELISPOT assays. Assays for antigen-specific CD4+ T cells sometimes measure the up-regulation of surface activation induced markers (AIM). However, these methods do not usually measure $\mathrm{T}$ cell avidity or test the potency of cells in viral inhibition assays (57). Here, we confine our discussion to ELISPOT assays, with some exceptions.

Depending on the vaccine candidate antigen, a $\mathrm{T}$ cell assay can use individual peptides, mostly derived from the $\mathrm{S}$ protein, pooled or matrix-pooled peptides, or protein or vector-expressed antigen as a source of peptides to bind to the MHC molecules that are expressed on the cell surface and recognized by a specific $\mathrm{T}$ cell receptor. As cross-reactive $\mathrm{T}$ cells are known to occur, most assays will not specifically identify a response that was elicited by prior exposure to a cross-reactive pathogen (or a different vaccine). For example, an earlier infection with one of the common cold coronaviruses might lead to a secondary memory response that could skew the outcome of the SARS-CoV-2 vaccine trial analysis, unless prior infection by those other coronaviruses is an exclusion criterion (which is rarely if ever the case).

ELISPOT results are usually expressed as spot forming cells (SFC) per $10^{6}$ input $\mathrm{PBMC}$, but this is not a uniform practice. For example, some investigators use $\mathrm{SFC} / 10^{5}$ cells as their read out; we multiply their values by 10 and report them as SFC $/ 10^{6}$ cells. We also use the abbreviation SFC rather than SFU when the latter is used in the original paper. There are also variations in methodologies, including the length of time between blood draw and cryopreservation, the method used for thawing, the peptide concentration used, the duration of peptide incubation with the cells, the time taken to complete the assay, and whether responding T cells are separated. All of these factors can affect an ELISPOT result and need to be considered when comparing different studies. A general feature of the papers we have summarized is a lack of detail on how the assays were performed. It would also be useful if images of key ELISPOT plates were provided as raw data, to allow the spots to be re-counted. The timing of when cell samples are collected after a vaccine prime or boost is also relevant. Thus, the time-dependent decay of circulating $\mathrm{T}$ cells affects the magnitude of the responses measured in 
vitro, to a greater extent than applies to the more stable antibody responses.

Concerns have been expressed that SARS-CoV-2 vaccines may exacerbate disease in infected animals, based on data arising in earlier animal model experiments with vaccines against other coronaviruses $(34,35,45,58-60)$. One particular potential problem is referred to as Vaccine-Associated Enhanced Respiratory Disease (VAERD; 59). While it is not possible to determine whether VAERD will be a problem with SARS-CoV-2 vaccines prior to the outcome of efficacy trials and post-licensure safety assessments, the pulmonary dysfunctions are associated with increased production of IL-4, 5 and -13, eosinophil recruitment and impeded CD8+ T-cell responses (59-61). This pattern of immune responses is indicative of Th2-polarization. Accordingly, some of the NHP and human experiments include analyses of in vitro cytokine release profiles, to seek signs of unwanted, Th2-biased responses. To date, Th2 responses have rarely been seen. We briefly note the outcomes of such analyses when they were performed.

\section{Immunogenicity of vaccine candidates in NHPs}

Immunogenicity studies have been performed in rhesus or cynomolgus macaques or, in one case, baboons (1-13). The immunogens were generally tested beforehand in small animals, often but not always mice, to provide initial assessments of their performance and to provide some indication of the dose or dose range to then evaluate in NHPs. Here, we focus only on the NHP studies themselves; the primary papers should be consulted for the small animal data. In general, the NHP experiments also involved safety assessments. The outcomes were unexceptional in that no significant problems were reported in the primary papers, which should, again, be consulted for details. Key serum antibody titer values recorded in this section are summarized in Table 2 and, for data obtained at the time of closest to challenge, also in Table 3 . T-cell response data are similarly summarized and tabulated, although these assays were not performed in several of the studies. In all cases, the vaccines were administered intramuscularly (i.m.), which also applies to the human clinical studies (see below). However, small-animal studies of a chimp adenovirus vaccine and an Ad5 vaccine (not the AstraZeneca/Oxford and CanSino clinical candidates, respectively) suggests that viral vectors might be very fruitfully delivered by the intranasal route instead $(50,62)$.

Usually, one or more sub-groups of macaques were rolled over into a SARS-CoV-2 challenge study, or the optimal regimen was tested in a de novo experiment. Some details and the outcomes of the virus challenges are summarized separately below and in Table 3 .

The first macaque immunogenicity paper to appear described PiCoVacc, the Sinovac ß-propiolactone-inactivated,
Vero cell-produced virus vaccine (1). (Note that this vaccine was renamed CoronaVac for human clinical trials (Table 1) (14). Two vaccine doses (3 $\mu \mathrm{g}$ and $6 \mu \mathrm{g}$ of viral protein) with an Alum adjuvant were tested on groups of 4 rhesus macaques via three immunizations on days 0,7 and 14. The $6 \mu \mathrm{g}$ dose elicited slightly the stronger antibody responses on day 21, when the anti-S-protein GM ELISA endpoint titers were $\sim 12,800$ and NAb GM ID $_{50}$ values were $\sim 50$ in an RV assay (Table 2). Antibodies specific for the RBD dominated the antibody response to the inactivated virus vaccine, which is relevant to understanding the outcome of the challenge experiment (see below).

The Sinopharm/BIBP inactivated virus vaccine, BBIBPCorV, was also produced in Vero cells and inactivated with beta-propionolactone. Mixed with Alum adjuvant, three different doses $(2 \mu \mathrm{g}, 4 \mu \mathrm{g}$ and $8 \mu \mathrm{g}$ of viral protein) were administered to groups of 10 cynomolgus macaques on days 0 , 7 and 14 (2). The resulting NAb titers, measured in an RV assay, were dose-dependent, with a GM ID ID $_{50}$ value of $\sim 210$ reported for the highest dose group on day 21 (Table 2).

The ChAdOx1 nCoV-19 recombinant virus vector expresses a non-stabilized form of the SARS-CoV-2 S-protein (3). Groups of 6 rhesus macaques received this vaccine $\left(2.5 \times 10^{10}\right.$ particles) either once (day 0) or twice (days 0 and 28) in a prime-boost protocol. In the single-dose group, the anti-Sprotein median endpoint titer on day 14 was $\sim 600$ and the median $\mathrm{NAb} \mathrm{ID}_{50}$ value was $\sim 20$ in an $\mathrm{RV}$ assay. The second dose boosted these responses to $\sim 28,000$ and $\sim 280$, respectively, on day 42 (Table 2). The animals were challenged with SARS-CoV-2 on day 28 (one-dose group) and day 56 (primeboost group), as summarized below (Table 3 ).

Rhesus macaques were used to identify and evaluate the optimal design of the Janssen Ad26.COV2.S vaccine candidate (4). First, antibody responses to seven different S-protein variants were compared using a range of assays, leading to the selection of the optimal Ad26 S.PP design. After a single dose of this immunogen, median RBD-ELISA endpoint titers at week 4 were $\sim 4000$, while the PV and RV NAb median ID $_{50}$ values were 408 and 113, respectively (Table 2). In an IFNgamma ELISPOT, at week 4 , the median response elicited by the S.PP vaccine was only $\sim 80 \mathrm{SFC} / 10^{6}$ cells. The data were insufficient to confidently assess the Th1 versus Th2 bias, as only IFN-gamma and IL-4 responses were measured. T-cell response data were presumably not factored into the decision to choose the S.PP construct as the clinical candidate, as this virus was the least immunogenic of the seven variants from the perspective of inducing CD4+ and CD8+ T cell immunity. The antibody responses were clearly prioritized (4). In a larger and more complex study, various Ad26.COV2.S vaccine dosing parameters were evaluated in adult macaques, including the number of virus particles administered $\left(5 \times 10^{10}\right.$ versus $1 \times 10^{11}$ ), the benefits of one- versus two-doses, and the 
interval between the first and second dose in a two-dose regimen (4 versus 8 weeks) (5). Antibody and T-cell responses were assessed using similar assays to the initial study (Table 2 ). The various inter-group comparisons showed that two doses of $5 \times 10^{10}$ virus particles given at weeks 0 and 8 was the preferred regimen for human studies (5). These findings presumably influenced the decision to begin a Phase 3 trial of the two-dose regimen, to supplement the ongoing one-dose trial (see below). An additional aspect of the macaque experiment was testing in aged macaques, defined as animals 3.3 to 5 years old. Here, the immunogenicity of the preferred twodose, 0- and 8-week regimen was found to be comparable to what was seen in the younger adult animals (5). One final element of the overall experiment was the use of an Alumadjuvanted recombinant, stabilized S-protein, principally for assessing Th1 versus Th2 bias compared to the Ad26 vector regimens. As expected, the responses to the Ad26 virus vectors were more Th1-polarized than those to the Alum-adjuvanted S-protein (5). No virus challenges were conducted.

DNA vaccines expressing 6 different SARS-CoV-2 S-protein variants, including the full-length S-protein and the RBD, were tested, without adjuvant, in rhesus macaques (6). Median endpoint anti-S-protein titers at week 5 varied moderately with the immunogen but were 140-180 for the fulllength S-protein and RBD immunogen groups. Midpoint NAb titers at week 5 also varied by immunogen, with median ID $_{50}$ values of $\sim 50-200$ and $\sim 30-40$ in PV and RV assays, respectively (Table 2). The full-length S-protein construct elicited somewhat stronger NAb responses than its RBD counterpart. At week 5, T-cell responses were detectable in ELISPOT assays with pooled S peptides $\left(\sim 80 \mathrm{SFC} / 10^{6}\right.$ cells in the S Group, Table 2). Intracellular staining showed IFN-gamma responses both in $\mathrm{CD} 4+$ and CD8+ subpopulations; the responses to full-length $\mathrm{S}$ were stronger than to $\mathrm{S} 1$ and RBD. Finally, IL-4 responses were barely detectable, which is compatible with a Th1 bias of the cellular immune responses (6).

Inovio's INO-4800 S-protein based DNA vaccine was given to 5 rhesus macaques in $1 \mathrm{mg}$ doses at weeks 0 and 4 by an i.m. electroporation device that provides a mild electric shock to open membrane channels in muscle cells (7). The peak anti-S-protein GM endpoint titer (week 6) was $\sim 130,000$, but dropped $\sim 40$-fold by the time of challenge at week 17. The binding antibody endpoint titers against the RBD were $\sim 5$-fold lower than against the S-protein at week 6 . In the PV NAb assay, the peak GM ID ${ }_{50}$ titers were $\sim 1000$ but had declined to $\sim 250$ by week 12 (i.e., a 4 - or 5 -fold titer decrease over 6 weeks against the two PVs tested). Low titers of anti S-protein IgG $(\sim 10)$ were also detected in bronchoalveaolar lavage (BAL) samples from vaccinated animals. An IFN-gamma ELISPOT was used to measure T-cell responses triggered by 5 peptide pools at week 6 . Signals were seen with PBMC from 4 of the 5 animals, with a range of 0 -
$518 \mathrm{SFC} / 10^{6}$ cells and an arithmetic mean (AM) value of $\sim 140$. By week 12, the mean value had declined to only $\sim 30$ (7).

The Moderna S-protein based vaccine candidate, designated mRNA-1273, was also tested in rhesus macaques (8) The lipid-encapsulated mRNA formulation was given i.m. at doses of $10 \mu \mathrm{g}$ or $100 \mu \mathrm{g}$ to each of two groups of 8 animals, at weeks 0 and 4 anti-S-protein ELISA data were presented only in the form of AUC values, precluding direct comparison with other studies. For the high-dose group at 4 weeks after the second dose, the NAb GM ID ${ }_{50}$ values in PV and RV assays were 1862 and 3481, respectively. In a CFC assay, Th1 responses were dose-dependent, while Th2 and CD8+ T-cell responses were at most minimal. Although all animals responded according to pre-specified criteria, the T-cell assay signals were generally weak, even at the highest vaccine dose. There were no differences in Th1- or Th2-associated cytokines or chemokines in BAL samples from the vaccine and control animals $(8)$.

A paper describing the immunogenicity of the Pfizer/BioNTech BNT162b2 S-protein expressing mRNA vaccine in mice and rhesus macaques appeared several weeks after one that reported on the performance of the same vaccine in humans (Tables 2-4) $(11,25)$. Either 30 or $100 \mu \mathrm{g}$ doses of the mRNA were given intramuscularly to the macaques on days 0 and 21. Serum anti-S1 antibodies were quantified by ELISA on days 21, 28, 35, 42 and 56 and presented as ELISA units per $\mathrm{ml}$ (derived from comparison with a standard curve). On day 28 these values were 30,339 and 34,668 for the 30 and $100 \mu \mathrm{g}$ groups, respectively, but had declined $\sim 5-7$ - fold to 4,236 and 6,317 by day 56 . The pattern of NAb data, assessed by an RV assay, was similar; the peak NAb GM ID I0 $_{50}$ values were 962 on day 35 and 1,689 on day 28 for the two dosing groups, but by day 56 they had dropped 4-5-fold to 285 and 310 , respectively. The inferred half-life for the early-phase decline is approximately 1 week for the binding antibodies (ELISA) and 2 weeks for NAbs, although the latter titers declined more rapidly at the later time points. Antibody decay rates this short are a potential concern for the longevity of any protection seen in humans, particularly if they are also seen in trials of the other vaccines. T-cell responses, measured by IFN-gamma ELISPOT on days 28 and 42, were $~ 750$ $\mathrm{SFC} / 10^{6} \mathrm{PBMC}$ for both dosing groups, with IL-4 responses below $250 \mathrm{SFC} / 10^{6} \mathrm{PBMC}(11)$.

A third S-protein based mRNA vaccine has now been described, MRT5500 from Sanofi Pasteur (13). Initial studies in mice led to the choice of a full-length S-protein construct, 2P/GSAS, that contains the commonly used two proline mutations (2P) and a furin cleavage site knock-out mutation (GSAS). The 2P/GSAS mRNA, formulated as lipid nanoparticles, was tested in a cynomolgus macaque dose-ranging study. Thus, 15, 45 or $135 \mu \mathrm{g}$ of the mRNA were given on days 0 and 28 , leading to NAb responses on day 35 that trended 
upwards in a dose-dependent manner. For the $135 \mu \mathrm{g}$ dose group, the NAb GM IC 50 titers were 2871 (PV assay) and 1877 (RV assay). PBMC T-cell responses, assessed using a cytokine release (ELISPOT) assay, were Th1-biased (IFN-gamma release but not IL-13). The magnitude of the macaque IFNgamma response was very low, around 30-40 SFC/10 6 PBMCs (Table 2). No virus challenge was performed (13).

The Novavax NVX-CoV3273 vaccine is an insect cell-derived S-protein that is mixed with detergent to form what are described as nanoparticles $(9,10,21,63)$. That formulation is combined with the Matrix $\mathrm{M}$ adjuvant. The immunogenicity study in baboons compared 1, 5 and $25 \mu \mathrm{g}$ doses of the S-protein in a two-dose (days 0,21 ) regimen, while a fourth group received $25 \mu \mathrm{g}$ with no adjuvant. Antibody assays on days 21 , 28 and 35 showed that the optimal dose was $5 \mu \mathrm{g}$ with adjuvant, with the peak response reached by day 28. The highest GM anti-S-protein $\mathrm{GM} \mathrm{EC}_{50}$ and $\mathrm{NAb} \mathrm{ID}_{>99}$ values were 174,000 and 17,000, respectively (9). The same protein/adjuvant combination was then tested in cynomolgus macaques (10). The animals were immunized on days 0 and 21 at different doses, with both the protein and adjuvant amount varying (protein at 2.5, 5 and $25 \mu \mathrm{g}$ doses). At the highest dose (25 $\mu \mathrm{g}$ S-protein, $50 \mu \mathrm{g}$ adjuvant, mirroring one of the human study groups, see below), the anti-S-protein $\mathrm{GM} \mathrm{EC}_{50}$ value on day 35 was 469,739 . Note that binding antibody data were presented as $\mathrm{EC}_{50}$ values, not the more usual endpoint titers, which would be substantially higher (perhaps 10-100-fold). In the RV NAb assay, the $\mathrm{CPE}_{100}$ (inhibition of $\sim 100 \%$ of the cytopathic effect, approximately equivalent to $\mathrm{ID}_{>99}$ ) was measured, with GM values ranging from 17,920-23,040 in the different dosing groups. It should be noted that the neutralization titers for near complete efficacy of neutralization measured in these studies $\left(\mathrm{CPE}_{100}\right.$ or $\left.\mathrm{ID}_{>99}\right)$ will be substantially lower than the more conventional $\mathrm{IC}_{50}$ values, although we cannot estimate by how much. In summary, the NAb titers in these papers are based on highly stringent assessments of virus neutralization, which should be borne in mind to avoid underestimating the clearly strong antibody immunogenicity of NVX-CoV3273 $(9,10)$.

Another recombinant S-protein vaccine has been tested in rhesus macaques, in this case from the company, Clover Biopharmaceuticals (12). The S-protein contains a C-terminal "TRIMER-Tag", to promote trimer formation and stability, and was produced in a high-yielding, stable $\mathrm{CHO}$ cell line. After pilot experiments in mice, rhesus macaques were given $30 \mu \mathrm{g}$ of the S-protein on days 0 and 21 in either AS03 or CpG/Alum adjuvant, or vehicle as a control (Table 2). On day 35 , the strongest anti-S-protein antibody responses were in the AS03 group (GMT endpoint titers of $\sim 17,497$ vs. $~ 3,157$ in the $\mathrm{CpG} /$ Alum). At the same time, the $\mathrm{GM} \mathrm{NAb} \mathrm{IC}_{50}$ titers in the AS03 group were 5,227 and 20,234 in a PV and a RV assay, respectively. The $\mathrm{D} 614 \mathrm{G}$ mutation in the recombinant trimer did not affect ACE2 binding or the competition therewith by murine immune sera. The partial protection observed in a virus-challenge experiment is summarized below (Table 3). A Phase 1 clinical trial of the S-protein with either AS03 or $\mathrm{CpG}$ /Alum adjuvant is now in progress in China (12).

\section{Outcome and interpretation of macaque challenge ex- periments}

When interpreting the outcome of macaque challenge experiments, it should be borne in mind that SARS-CoV-2 does not cause a lethal COVID-19 like disease in these animals. The macaques do become ill, rhesus perhaps more so than cynomolgus, but the disease course is generally mild, self-limiting and overcome within $\sim 2$ weeks $(51,64-66)$. In general, the various vaccines reduce the severity of this mild disease, including by reducing or even preventing the transient lung damage that can be seen in post-mortem samples taken from control animals. No signs of vaccine-mediated enhancement of infection, including VAERD, were reported. The most common way in which vaccine efficacy is assessed is by determining the viral load (VL) in samples from various locales and tissues at short intervals during the week after challenge. In some experiments, both viral RNA copies per ml and subgenomic RNA copies per $\mathrm{ml}$ are determined, the latter avoiding problems associated with the presence of residual challenge virus and more unambiguously demonstrating viral replication in the infected animal $(6,51,67)$ (Table 3$)$. Lung pathology was also generally assessed, although the criteria chosen tend to vary among the different experiments. For a particularly detailed discussion of the variables associated with challenge experiments in macaques and how they are best interpreted, see (51).

Antibody titers in the animals on or very close to the day of challenge were reported in some of the papers and are summarized below and also in Table 3. In the other papers, the antibody data were derived at an earlier time point (Table 3 ). The inconsistencies in how the different studies were conducted and/or reported is another factor that blurs attempts to compare and interpret the performances of the different vaccines. Only four of the reports include data on T-cell responses at any time point prior to challenge, which limits understanding of any role they may play (Table 2) (4-7). In a separate section, we discuss what, if any, correlates of protection (CoP) can be inferred from some of the challenge experiments.

Most of the experiments involved SARS-CoV-2 challenges within a few weeks of the final (or only) vaccine dose, i.e., at a time when the immune response is likely to be close to its peak. The exception is the Inovio DNA vaccine study in which the challenge was delayed by 13 weeks (7). The next longest delays are 55 days after the second dose of the BNT162b2 mRNA vaccine and 42 days after the delivery of a single dose 
of the Ad26.COV2.S vaccine (Table 3$)(4,11)$. Thus, it is not yet known whether these various vaccines would be as effective against challenges conducted many months after the immunization protocol was completed. Extrapolating to what might happen when vaccinated humans become exposed to SARS-CoV-2 over the subsequent months or years is not possible.

Another issue when considering these macaque experiments concerns the SARS-CoV-2 challenge itself. There is no generally accepted standard, and various different challenge virus stocks (in several cases, of unspecified origin) were used. The challenge dose also varies by 100 -fold and the route of challenge is another variable (Table 3 ). In one experiment, the virus was even administered by four different routes (3). All of these protocol variations constitute yet another factor hindering cross-study comparisons $(34,51)$. As a general principle, it will be easier to protect against a low dose of a challenge virus than a higher one, all other things being equal. Thus, would a vaccine that protected against a relatively low challenge dose be as protective against the 100-fold higher dose used in other experiments $(34,51)$ ? Or would its protection break down under those conditions? We return to this point at the end of this section. Challenge doses for vaccine experiments are traditionally pre-determined in naïve animals, to identify an inoculum size that is neither too low to be consistently infectious nor too high to protect against. It is rarely clear from the papers whether such titrations were performed. In one report, nasal swab VLs taken from SARSCoV-2-infected humans and from the virus-challenged macaques soon after infection were said to be comparable $(\sim 1 \times$ $10^{6} \mathrm{RNA}$ copies/ml) (8). However, the initial infection and subsequent replication efficiencies are likely to differ substantially between the two species so it is not clear that this comparison is meaningful.

In the Sinovac PiCoVacc study, groups of 4 rhesus macaques were immunized with either $3 \mu \mathrm{g}$ or $5 \mu \mathrm{g}$ of the inactivated virus vaccine on days 0,7 and 14 and challenged intratracheally with the CN1 strain of SARS-CoV-2 on day 22 (1). At this time, the anti-S-protein GM endpoint titer was $\sim 12,800$ while the NAb GM ID I0 $_{50}$ titer was $\sim 50$ when measured 7 days earlier. All the vaccinated animals became infected after challenge, but disease severity was reduced compared to the control group (adjuvant-only) as judged by lung pathology assessments. VLs (i.e., viral RNA) was frequently detected at high levels in lung samples from control animals but in none of the high-dose vaccine recipients and only sporadically at significantly lower levels in the low-dose group. Viral RNA) levels in throat swabs were also lower and declined more rapidly, particularly in the higher vaccine-dose group (Table 3). The observed increases in NAb titers after day 7 post-infection may be consistent with an anamnestic antibody response (1).
The Sinopharm/BIBP inactivated virus vaccine experiment involved two groups of 4 cynomolgus macaques that were immunized with different doses $(2 \mu \mathrm{g}$ or $8 \mu \mathrm{g}$ of viral protein) on days 0 and 14 (2). Binding antibodies were not measured. The NAb GM ID 50 values in an RV assay were $\sim 200$ and 230 in the low and high dose groups when the animals were challenged on day 24 with a SARS-CoV-2 isolate from the Chinese Center for Disease Control and Prevention, by the tracheal route (Table 3 ). There were no changes in body temperature in either the vaccine or placebo groups over the next 7 days, which is indicative of a mild disease course. Viral RNA in all lung lobes was analyzed post mortem, but none was detected in any lobe taken from vaccine recipients (in either dosing group). In contrast, the RNA copy number per ml ranged from $\sim 30,000$ to $3,000,000$ in the lower lobes of the control animals. Lung pathology was also prevented or reduced in the vaccine groups. Although viral RNA in throat swabs became undetectable 7 days after challenge in the high-dose group, other evidence suggests these animals did become infected, albeit to a much lesser extent than the control and low-dose vaccine groups. Thus, gastrointestinal virus (detected in anal swabs) remained stable in the high-dose at $\sim 100$ RNA copies per ml from day 3-7, whereas the corresponding values in the two other groups fluctuated in a range around 100,000. While this study only analyzed viral, not subgenomic, RNA, it seems highly unlikely that gastrointestinal viral RNA could simply represent residual challenge virus. Thus, the higher-dose animals were at least strongly, but apparently not completely, protected from infection, and in both dosing group the vaccine reduced the extent of virus replication post-infection (2).

All 12 of the ChAdOxl-vaccinated macaques became infected when they were challenged 28 days after their final immunization (they received either 1 or 2 vaccine doses, see above) (3). The SARS-CoV-2 challenge strain was WA1-2020 (MN985325.1). At the time of challenge, the median binding antibody endpoint titers were $\sim 6,300$ with median $\mathrm{NAb} \mathrm{ID}_{50}$ values of $\sim 60$ in a RV assay (Table 3 ). The vaccinated animals had fewer symptoms than the control group, less lung damage and lower VLs (measurements included subgenomic RNA) in BAL and lung samples. No virus was detected in BAL samples from the vaccinated animals on day 5 , but subgenomic RNA could be detected in lung samples from some animals in both groups. No antibody or T-cell data postchallenge were reported, so it is unknown whether there were anamnestic responses to the infecting virus (3).

Seven different Ad26-based vectors were given once to groups of 4-6 rhesus macaques before challenge 6 weeks later with an unspecified isolate of SARS-CoV-2 (4). Compared to a control group of 20 animals, VLs in BAL and nasal swabs were significantly reduced in each of the 7 Ad26 vector groups, by $>5$ - $\log$ in the case of BAL samples. The best 
performing vector, from this perspective, was the one designated S.PP; it was chosen to become the Ad26.COV2.S clinical vaccine candidate. Overall, the authors assessed that 17 of the 32 vaccinated macaques were protected from infection, judged by the VL data. There was no evidence for anamnestic B- and T-cell responses in the protected Ad26.COV2.S vaccinated animals, although NAb titer increases were seen in other vaccine groups. The strongest, and perhaps complete, protection was seen in the S.PP group. Thus, virus (subgenomic RNA) could not be detected in BAL from $6 / 6$ and in intranasal swabs from 5/6 animals (4). More recently, hamsters immunized once with the S.PP-expressing Ad26 clinical vaccine candidate were protected from severe disease when challenged with SARS-CoV-2 nasally 4 weeks later (49).

In another study, rhesus macaques were immunized i.m. with S-protein-expressing DNA plasmids at weeks 0 and 3, and challenged at week 6 with an unspecified SARS-CoV-2 isolate (6). All of the 10 control animals became infected, with BAL and nasal swab peak subgenomic RNA levels copies in the range $10^{4}-10^{7}$ per ml. However, 8 of the 25 vaccine recipients were RNA-negative in BAL and nasal swab samples while median subgenomic RNA levels in the other 17 macaques were 3-4 logs lower than the median values from the 10 control animals. Even when subgenomic RNA was undetectable in vaccinated animals, the observation of anamnestic antibody and T-cell responses does imply that the animals were not completely protected from infection. Instead, initially replicating virus may have been suppressed by vaccinemediated immunity (6).

The Inovio INO-4800 DNA vaccine was given to 5 rhesus macaques at weeks 0 and 4 (7). The SARS-CoV-2 challenge (USA-WA1/2020 strain) was then delayed until week 17 (i.e., 13 weeks after the second immunization), a substantially longer period than applies in the other studies summarized here. Upon challenge, all the macaques became infected, judged by VLs in various samples. However, VLs in the vaccinated group were lower and declined more quickly than in 5 control animals, the reduction in medians being in the $<10$ 300 -fold range depending on the sample site and the time point assayed; the difference was significant for BAL but not intranasal swab (INS) samples. Antibody and T-cell recall responses were quantified in the animals after virus challenge. Thus, by 14 days post-challenge anti-S-protein antibody and NAb measurements were higher ( $10-30$ fold) in the vaccinated than control animals, while there was an $\sim 2$-fold increase in INF-gamma signals. Overall, the vaccine-mediated reduction in viremia post-challenge was attributed to recall responses (i.e., T- and B cell memory) (7).

Two dosing groups of 8 rhesus macaques were immunized with the Moderna mRNA-1273 vaccine at weeks 0 and 4 and then challenged with the USA-WA1/2020 strain of SARS-CoV2 at week 8 (8). Judged by VLs, most ( 7 of 8 ) of the animals in the higher dose group were protected, but most ( $\sim 5$ of 8 ) of the lower dose group became infected (the exact numbers vary per time point, and depend on the VL sample site). There were indications of anamnestic responses in some animals, including in BAL. Post-mortem analyses of the lungs found little or no signs of inflammation in the higher-dose group, but some indications of pathology in the lower dose animals that became viremic. Neutralization titers in both PV and RV assays correlated inversely with INS viral loads; virus-specific IgG and IgA levels in BAL were elevated in the high dose group on days 2-7 post-challenge, an anamnestic response that may perhaps have contributed to VL reduction. In the high-dose, high-protection group, the GM $\mathrm{ID}_{50}$ values from PV or RV NAb assays were $>900$ in $7 / 8$ animals, whereas the corresponding values were $<900$ for $7 / 8$ animals in the lowdose, low-protection group. The data pattern implied that NAbs were protective in the high-dose group (8).

In the BNT162b2 vaccine study, 6 rhesus macaques immunized on days 0 and 21 with $100 \mu \mathrm{g}$ of the mRNA and 3 naïve controls were challenged on day 76 overall with $1.05 \times$ $10^{6} \mathrm{PFU}$ of the USA-WA1/2020 strain of SARS-CoV-2 by the IN-IT routes (11). Antibody titers on the day of challenge were not reported, but measurements made on day 56 are summarized above and in Tables 2 and 3. Infection was monitored by viral RNA copies in BAL, nasal swabs and oropharyngeal swab on days 3, 6 and 10. No viral RNA was detected at any time in the BAL samples from the immunized macaques but was present control samples. A similar data pattern, after day 1 , was seen when the nasal swabs were analyzed, and in the oropharyngeal swabs, $2 / 6$ were positive on day 3 . The GM reductions in VL measured as viral RNA copies 3.0 log for BAL, $1.5 \log$ for intranasal swabs and $2.5 \log$ for oropharyngeal swabs (the first and last of which were statistically significant). One unusual aspect of the experiment was that the complete absence of disease symptoms in the control animals (and, of course, also in the vaccine recipients). As noted above, SARS-CoV-2 infection generally causes moderate disease in rhesus macaques, including in other vaccine experiments. Why no such symptoms were seen in the present study was not explained but could perhaps be rooted in the challenge virus stock or the origins of the macaques (11).

The adjuvanted Novavax NVX-CoV2373 recombinant protein vaccine was given to cynomologus macaques on days 0 and 21 before the animals were challenged with the WA1 strain of SARS-CoV-2 via the nasal and tracheal routes on day 35 (10). Judged by VLs (subgenomic RNA) in BAL and nasal swabs, performed 2 and 4 days later, every animal was virusnegative except for one in the lowest dose group that had a weakly positive BAL sample. Post-mortem lung samples in the vaccine groups showed no sign of the pathologies that were visible in the control animals. To the extent that can be judged, the vaccinated animals may have been completely 
protected from infection. This outcome may reflect the very high GM antibody titers on the day of challenge (anti-S-protein $\mathrm{EC}_{50} 469,739$, NAb CPE $100,23,040$ ) (10).

Clover Biopharmaceuticals tested their recombinant "TRIMER-Tag" S-protein plus AS03 or CpG/Alum adjuvants in rhesus macaques (12). After two vaccine doses on days 0 and 21, the animals were challenged on day-35 using $2.6 \times 10^{6}$ TCID $_{50}$ of SARS-CoV-2 by the IN+IT routes (Table 3 ). Both of the trimer/adjuvant groups of animals were partly protected as measured by body mass and temperature and VL in throat, anal and tracheal but less so in nasal swab samples. However, VLs in the lungs indicated complete protection in both of the trimer groups, compared with the vehicle controls. Serum Ab responses dropped a little in the week post-challenge, which the authors suggested reflected the formation of immune complexes with the incoming virus and hence $\mathrm{Ab}$-mediated virus clearance (12). Whether this explanation is correct remains to be determined.

In summary, all of the vaccines tested to date have conferred a substantial degree of protection to the immunized macaques. In some macaques, there is reasonable evidence for complete protection (i.e., 'sterilizing immunity'), but the more common outcome is a reduction in the severity of the already mild disease course seen in control animals. We discuss in the next section what immune factors and other variables may have influenced the outcomes of the different experiments. In respect of what the outcomes may mean for vaccine efficacy in humans, we note that it is generally easier to protect animals against mild infections than severe ones. Hence, it is hard to assess whether and how any of the present findings in macaques might translate to the subset of humans who need protection from severe and lethal COVID19. Moreover, as noted above, it is not known whether the various vaccines would still protect macaques, and by extrapolation humans, after a substantial period (multiple months) has elapsed.

\section{Toward correlates and mechanisms of protection}

It is striking that in the various macaque immunization studies, similar outcomes of virus challenges were associated with substantial ( 2000-fold) differences in serum antibody titers to the S-protein, the recombinant protein vaccines being the strongest immunogen for inducing binding antibodies $(9,10)$ or NAbs $(9,10,12)$ (Table 2$)$. It can also reasonably be concluded the ChAdOx1 vaccine is not a strong inducer of antibody responses to the S-protein, particularly when given only once (Table 2) (3). The same conclusion can be made about the DNA plasmid vaccines (Table 2) $(6,7)$. Are the serum antibody responses induced by the weaker vaccines solely responsible for any protection that was conferred? Perhaps cellular immune responses or some other unmeasured factor, such as mucosal IgA, were contributory? The potential protective role of mucosal immunity is highlighted by the outcomes of experiments involving a ChAd virus vector in mice (38). These observations are similar to those in studies of other vaccines, such as HIV-1 Env, where only proteinbased immunogens induce very strong antibody titers (68).

What protected the vaccinated animals from SARS-CoV-2 infection and/or disease? CoPs are important in vaccine development, because they can serve as robust predictors of future vaccine efficacy whether they are derived from animal experiments or clinical trials and whether the endpoints involve protection from infection or a reduction in disease severity. There are nuances to the identification of CoPs in population-wide studies that we cannot address here $(69,70)$. The present macaque-challenge studies are not sufficiently powered and are not wide-ranging enough in scope to allow the identification of CoPs with high confidence. The few attempts to identify CoPs have pointed toward a predominant role for NAbs, which is not unexpected, but it is premature to conclude that NAb titers at the time of challenge (i.e., in humans, virus exposure) tell the entire story. The possible role of recall responses (i.e., T- and B cell memory) in clearing a transient infection has only been addressed in the Inovio DNA vaccine study, which involved the longest delay between immunization and challenge (Table 3). Even in that experiment, the amount of information available is quite limited (7).

Despite the limitations of the available data, we sought hints of CoPs. Thus, we analyzed the relationships between, on the one hand, binding antibody and NAb titers at the prechallenge peak or within two weeks before challenge and, on the other hand, VL reductions in vaccinated animals compared with controls (summed for two locales of sampling and based only on subgenomic RNA; Tables 2 and 3). We found no tangible non-parametric (Spearman) positive correlations of any significance between VL reduction and any antibody parameters, which is not surprising given the number of variables between the different experiments. We were also unable to identify any consistent relationship between the challenge virus dose or delivery route and the degree of protection. The challenge dose was not a consistent predictor of the magnitude or duration of high viral loads in the control animals, but we should bear in mind that the challenge virus stocks represent another variable, as does the sub-species (and sources) of the animals involved. Nonetheless, the wide variation in challenge dose between experiments should not be ignored. Would a vaccine that protected against a relatively low challenge dose be as protective against the 100-fold higher dose used in other experiments? Or would its protective capabilities degrade under those conditions? Experimental conditions yielding high VLs in control animals may impede complete protection while giving the potential for greater VL reductions. The smallest VL decrease in the 
vaccine group compared to control was seen in the Inovio DNA vaccine experiment which involved one of the lowest challenge doses (Table 3) (7). In the report on the Ad26.COV2 vaccine, there were indications of sterilizing immunity when an intermediate challenge dose was used (4).

In four studies, some groups of vaccine recipients seem to be completely protected, or nearly so $(4,6,10,11)$. In one experiment, no anamnestic antibody or cellular immune responses were detected in the protected animals, which suggested that immunity was sterilizing (4). However, in another study there were anamnestic immune responses in animals with undetectable VLs, which is more indicative of incomplete but aborted infection (6). Anamnestic responses were not analyzed in the third report (10). In two other cases, lung lobes in the vaccine groups where protection was strongest were free of viral RNA 7 days after infection, which contrasted to the high levels found in the lower lobes of control animals $(1,2)$. The criteria for sterilizing immunity, or at least complete protection against persistent infection, are neither defined nor standardized in the SARS-CoV-2 animal model field, which also extends into other protection-challenge systems involving small animals and both vaccines and antiviral antibodies (34, 51, 64-66).

Within individual studies there are fewer confounding factors than in a cross-study meta-analysis. Some evidence was presented that antibodies were the CoP in the Moderna mRNA vaccine study (8). In the report on the Janssen Ad26.COV2 vector vaccine, comparing various antibody and T-cell responses with infection outcomes (as judged by VLs) identified NAbs as the strongest $\mathrm{CoP}$, with some possible contribution from Ab-effector functions such as antibody-dependent cellular phagocytosis and antibody-dependent activation of natural killer cells. In contrast, T-cell responses (measured by ELISPOT or intracellular cytokine staining; ICS) did not correlate with protection (4). Similar inferences about an antibody but not a T-cell CoP emerged from the experiments involving DNA plasmid immunizations (6). But even when significant differences were identified, the ranges of the various measurements were generally overlapping between completely and partially protected animals $(4,6)$. This degree of variation compromises attempts to identify the threshold response required for protection, particularly in the study of the Ad26 vector vaccine (4). Overall, the available evidence from macaque-challenge experiments does point toward a protective role for antibody-based immunity (probably NAbs), but not to the extent that a protective titer can be inferred and then extrapolated to the outcome of human efficacy trials.

\section{Immunogenicity of vaccine candidates in humans}

Key antibody and T-cell response data summarized below for individual trials are presented in Table 4. As with the NHP studies, the primary papers and reviews should be consulted for additional details of the human trials, which are variously described as Phase 1, Phase 2 or combined Phase 1/2a trials (14-32). Vaccine safety assessments were a key component of these trials; in all cases, reported side effects and adverse events were considered to be minor or moderate; the primary papers contain the details, which we have not attempted to summarize. A grade 3 serious adverse event (SAE) due to a neurological complication happened in the AstraZeneca/Oxford vaccine Phase 3 trial in the UK, leading to a now-concluded pause while the case was investigated. A placebo recipient in the Brazilian arm of the Phase 3 trial of this vaccine reportedly died of COVID-19. An SAE, also triggering a temporary clinical hold, occurred in the Janssen Phase 3 trial, although no details have been reported.

Details of the Phase $2 b / 3$ efficacy trials for vaccines reaching that stage can be found at: (https://clinicaltrials.gov/ct2/results?recrs=\&cond=Covid19 $\&$ term $=$ vaccine $\&$ cntry $=\&$ state $=\&$ city $=\&$ dist $=)$. The preliminary outcomes of the Pfizer/BioNTech, Moderna, Gamalaya Center and AstraZeneca Phase 3 trials, as judged by information in press releases, are summarized in a separate section later in this article.

The initial human trials have predominantly involved young or middle-aged, healthy adults (see primary papers for details). Some information is becoming available on age-dependent decreases in immunogenicity. In the CanSino Ad5nCoV vaccine, participants aged older than 55 responded with weaker antibody responses than their younger counterparts. However, that outcome could reflect either the aging process or time-dependent increases in exposure to other Ad5 viruses that compromise expression of the immunogen from by the vector (24). An $\sim 2$-3-fold reduction in antibody responses was seen in older adults (aged 65-85) compared to younger ones (aged 18-55) in a Pfizer/BioNTech mRNA vaccine trial (27). Moderna has now reported similar findings for their mRNA vaccine; in a small-scale (40 volunteer) extension to their original Phase 1 trial, antibody and NAb responses were comparable in volunteers aged 56-60 and over 71 and similar to what was reported for those in the 18-55 age range $(19,20)$. NAb responses were slightly lower in volunteers aged over 60 than in ones in the 18-59 range, during the BBIBPCorV inactivated Phase 1 trial. The ratio was $\sim 2$-fold, but varied with the time point and vaccine dose, and group sizes were small (15). The Sinovac inactivated virus vaccine trial only involved volunteers under 60 , but an analysis of the 1829 vs. 50-59 age groups suggested that NAb responses were $\sim 2$-fold higher in the younger people. Overall, there was a modest trend toward weaker immunogenicity with age (14). A limited amount of preliminary data on the Janssen Ad26.COV2 vaccine also indicates that immunogenicity in volunteers aged over 65 is only modestly reduced (18). When 
the ChAdOx1 nCoV-19 vaccine two-dose regimen was tested in volunteers aged $18-55,56-69$ or over 70 , there was little or no age-dependent reduction in immunogenicity, judged by the same suite of antibody and T-cell assays used in the earlier trial $(16,17)$. In a macaque study, the immunogenicity of the Janssen Ad26.COV2 vaccine was comparable in adult and aged animals (5).

Taken together, the studies summarized above are encouraging for the efficacy of the various vaccines in older adults being comparable to what is seen in the Phase 3 trials that are being mostly conducted in younger people.

There has also been an under-representation of minority groups in the USA and European trials, so again information on how immunogenicity might vary in different populations is lacking. These various lacunae will need to be filled in Phase 3 trials, given that COVID-19 is more severe in older people and in African-American and Latinx populations.

\section{Inactivated virus vaccines}

The Sinopharm/WIBP inactivated virus vaccine was delivered in Alum adjuvant. It was first tested in 96 volunteers in a Phase 1 trial and then in 224 more people in a Phase 2 study (22). The study cohorts were based on healthy individuals aged from 18-59. The Phase 1 trial was dose-ranging $(2.5,5,10$ $\mu \mathrm{g}$ of viral protein) and involved i.m. injections on days 0,28 and 56, while in Phase 2 only the $5 \mu \mathrm{g}$ dose was tested in two sub-studies that involved immunizations on days 0 and 14 or on days 0 and 21. Immune responses were measured by ELISA using inactivated virus as the detecting antigen, which does not allow a comparison with other vaccines, and by a RV neutralization assay. For sera collected 14 days after the final dose, the NAb titers (GM ID $_{50}$ values) in the Phase 1 trial were 316, 206 and 297 in the low, medium and high dose groups respectively. Allowing for the titer ranges among participants, the three doses induced similar antibody responses. In the Phase 2 trial, the corresponding NAb titer values were 121 and 247 for the 0, 14 day and 0,21 day groups, respectively. Anti-virus ELISA endpoint GM titers were also similar among the different test groups in the two trials, and were $\sim 200-300$ in Phase 1 and $\sim 90-200$ in Phase 2 (Table 4). There were no T-cell data in the paper. Phase 3 trials are now in progress in South America, although the vaccine dose and delivery regimen (i.e., the number and spacing of doses) was not specified in the report on the Phase 1 and 2 trials (22).

Sinovac's PiCoVacc inactivated vaccine was renamed CoronaVac prior to Phase 1 and 2 human trials (Table 1, 3) (1, 14). The production process used to make the vaccine was stated to be changed between the Phase 1 and 2 trials to yield a product with an $\sim 2$-fold higher S-protein content, which the authors suggest improved its immunogenicity (14). However, only data from the Phase 1 trial have been reported to date, the Phase 2 results still pending. For Phase 1, the Alum- adjuvanted vaccine (or a placebo) was given to 600 adults aged 18-59 years in a two-dose regimen on days 0 and 14 or days 0 and 28. For each of the two regimens, two vaccine doses, $3 \mu \mathrm{g}$ and $6 \mu \mathrm{g}$, were tested in 120 volunteers, compared to a placebo group of 60 . The safety profile was unexceptional. Antibody responses were measured on days 28 and 42 in an anti-RBD ELISA and NAbs in an RV assay with a CPE readout (the cutoff for neither assay was reported). Anti-RBD GM titers were 1000 in all the four vaccine groups on day 28. The NAb GMT values for all the groups at all the time points were generally in the $32-64$ range (Table 4 ). The agedependency of the antibody responses was noted above. No T-cell data were reported (14).

The BBIBP-CorV Alum-adjuvanted inactivated virus vaccine also advanced from macaque studies into Phase 1 and 2 human trials (15). The Phase 1 trial involved 192 volunteers aged 18-59 and 60 or older, who received vaccine doses of 2, 4 and $8 \mu \mathrm{g}$ on days 0 and 28 . Only volunteers in the younger age-range participated in the Phase 2 trial, in which 448 people received a single vaccine dose of $8 \mu \mathrm{g}$ or two $4 \mu \mathrm{g}$ doses given first on day 0 and then on day 14, 21 or 28 . Taken together, the trials involved multiple small sub-groups, which limits the statistical power of any comparisons. The paper should be consulted for details of how the different dosing regimens performed. The vaccine was generally safe, with only minor adverse events reported. Immunogenicity was assessed only in an RV NAb assay. The resulting NAb titers were modestly dose-dependent, were much stronger after two doses than one, and were slightly lower in the younger than older age groups. In Phase 1 , the $8 \mu \mathrm{g}$ on day 0 and 28 regimen gave a GM titer of 228.7; in Phase 2, the highest NAb titers were seen in the group given an $8 \mu \mathrm{g}$ dose on day 0 and 21 , for which the GM titer was 282.7 (Table 4). No data on ELISA anti-virus or anti-S-protein titers, or on T-cell responses, were reported. Phase 3 trials are underway, using a two-dose regimen, but no details of the doses and scheduling chosen were provided (15).

A fourth Alum-adjuvanted, inactivated virus vaccine, from IMB/CAMS/PUMC, has also entered human trials, although no preclinical data were reported (29). This vaccine virus, KMS-1, was also produced in Vero cells but, unlike the other three, it was inactivated first with formaldehyde before betapropionolactone treatment. In the Phase 1 trial, the IMB/CAMS/PUMC vaccine was given twice to 192 people aged 18-59 on days 0 and either 14 or 28 , at doses of 50,100 or $150 \mathrm{EU}$ (the stated unit of antigen content). There were no significant adverse events and sera from selected volunteers did not trigger antibody-dependent enhancement in vitro. Immunogenicity was assessed at several time points using an RV NAb assay, via various ELISAs including anti-S-protein and anti-virion, and by IFN-gamma ELISPOT. The paper should be consulted for data on the 9 individual sub-groups 
in the trial, but in general the GMT NAb titers (CPE with unspecified cutoff) were all $<100$ and often $<50$. Anti-S-protein GM titers (with no cut-off specified) were 2000-4000 for the two highest doses of immunogen (Table 4). Only limited data were presented for the day 0,28 group after the second dose. Thus, on day 90, the GMT NAb titer was $<10$ and the anti-Sprotein titer was $\sim 500$, which indicate a time-dependent reduction in the initial antibody levels. IFN-gamma ELISPOT assays using $\mathrm{S}$ peptides gave AM values of $30-250$ per $10^{6}$ cells for the two vaccine doses, indicative of a generally weak Tcell response (29). In a Phase 2 study, 742 adults (aged 18-59) were given the higher dose of the inactivated vaccine on days 0 and 14 (30). The binding $\mathrm{Ab}$ and NAb titers reported were similar to those seen in the Phase 1 trial, but T-cell responses were not analyzed (Table 4).

\section{Adenovirus vector vaccines}

In a Phase 1 trial, the immunogenicity of the CanSino Ad5nCoV vaccine candidate was found to be dose-dependent (23). Doses of $5 \times 10^{10}, 1 \times 10^{11}$ or $1.5 \times 10^{11}$ virus particles were given once to three different sub-groups. In the highest dose group, the anti-S-protein and anti-RBD GM titers on day 28 were 596.4 and 1445.8, respectively (in references 12 and 13, the cut-offs for titer determinations are not specified; we refer to them as "titers"). The GM NAb titers were 34.0 and 45.6 in RV and PV assays, respectively, and were strongly correlated with anti-S and -RBD titers. A Phase 2 trial was then conducted on 508 participants, of which 126 received a placebo (24). The protocol again involved a single administration of the Ad5 virus, which was tested at doses of $1 \times 10^{10}$ or $1.5 \times 10^{10}$ in sub-groups. The anti-RBD GM titers on day-28 was 656.5 range, which is a $\sim 2$-fold lower than in the Phase 1 trial. NAb titers in the RV and PV assays were 19.5 and 61.4, respectively, and hence similar to the Phase 1 trial data. T cell responses were measured by ELISPOT on samples taken before vaccination and then on days 14 and 28 . Freshly drawn PBMC were incubated with S-protein peptide pools for $>12$ hours, with the data expressed as $\mathrm{SFC} / 10^{5}$ cells after subtraction of background values derived from unstimulated control cells. (Note that the data in Table 4 have been adjusted to $\mathrm{SFC} / 10^{6}$ cells to facilitate comparison to other datasets). There was no mention of a positive control method, nor of the number of replicates. An ELISPOT result was stated to be positive if the number of IFN-gamma secreting T cells responding to the S-protein peptides was increased 2 times above baseline post vaccination. TNF-alpha, IL-2 and IFNgamma responses to the vaccine were also assessed by CFC. $\mathrm{T}$ cell responses peaked at day 14 post vaccine, and ranged from $200 \mathrm{SFC} / 10^{6}$ cells in the low dose group to $580 \mathrm{SFC} / 10^{6}$ cells in the high dose group. In CFC assays, both CD4+ and CD8+ T cells were found to be responsive (24).

AstraZeneca's ChAdOx1 nCoV-19 recombinant virus vaccine (also known as AZD1222) was tested in a randomized Phase 1/2 trial involving 543 people; another 544 participants were given a meningococcal control vaccine (16). The original protocol involved a single dose of $5 \times 10^{10}$ virus particles, which is twice the amount given to macaques (Tables 2 and 4). However, a decision was taken during the trial to give ten participants a second dose of ChAdOx1 on day 28 in a nonrandomized boosting protocol. It is assumed that the decision was taken because of the limited immunogenicity of the single-dose regimen (a modest boosting effect of a second dose was seen in the NHP study, see above; 3). Anti-S-protein binding was measured at single dilutions and converted to "ELISA Units", an approach that complicates comparisons with antiS-protein responses to other vaccine candidates in humans and that represents an unexplained change from how the macaque sera were analyzed by titration in ELISA (3). By day 14 and 28, the responses in most of the participants were in the 100-1000 Units range (medians 102.7 and 157.1, respectively), with little change by day 56 in the sub-group that was assayed at that time point (median 119). After the second vaccine dose in the prime-boost protocol, a $\sim 5$-fold increase in median anti-S-protein ELISA Units was measured 14 days later (median 997.5), and the levels were largely maintained by day 56 (median 639.2). NAbs were measured 14 days after the booster immunization using one PV and three different RV assays. NAb data from the PV assay and from the only RV assay that reported $\mathrm{ID}_{50}$ values are given in Table 4 . The primary paper should be consulted for other aspects of the neutralization data generated in various assays (16). Overall, the apparently modest NAb responses to the single-dose vaccine were increased a few-fold by the day 28 boosting immunization, at least in the short term (until day 42). The median titers for the prime-boost group on day 42 were $372-450.9$ (Table 4). ELISPOT assays were performed on freshly isolated PBMC at days 0, 7, 14, 28 and 56, and at day 35 for the participants who received 2 doses. Pooled peptides were used as antigens, and data were excluded if the assay background response rate was deemed to be too high. The measured responses peaked at day 14 at a value of $856 \mathrm{SFC} / 10^{6} \mathrm{PBMC}$ in the prime group and $1642.3 \mathrm{SFC} / 10^{6} \mathrm{PBMC}$ in the prime-boost group (i.e., after one dose in either group). The results for other time points are given in Table 4 . Of note is that $\sim 10 \%$ of recipients of this vaccine appear to generate no measurable $\mathrm{T}$ cell response after the first dose. Furthermore, the booster dose given to ten trial participants did not further increase their T-cell responses (16). The initial UK-based Phase 1/2 clinical trial was extended to encompass 20 different subgroups with variables that included the number of vaccine doses (one or two) given to volunteers in three different age groups: $18-55(\mathrm{n}=100), 56-69(\mathrm{n}=120)$ and $70+(\mathrm{n}=200)$ (17). Control group members were given a Meningitis vaccine. Since there were 560 volunteers in total, the number of 
people in each individual sub-group was necessarily small, which limits the statistical power of any comparisons between the sub-groups. Nonetheless, the data pattern supported the use of two doses in the subsequent Phase 3 trial. The immunogenicity of the two-dose regimen was comparable among the different age groups, judged by the same suite of antibody and T-cell assays used in the earlier trial $(16,17)$. However, the confidence intervals on the various data sets are quite wide, which may have prevented the detection of modest differences. It was also noted that reactogenicity diminished with age (17). This vaccine has now advanced into Phase 3 trials in several international locations, including Brazil and South Africa. These trials were initiated as a single-dose regimen but were later changed to incorporate the second, boosting dose. A two dose Phase 3 trial started in the USA at the beginning of September, 2020.

The initial Phase 3 trial of the Janssen Ad26.COV2 adenovirus vector involves a one-dose regimen. Some of the human immunogenicity data on which this scheme was reportedly based have been described in an 'interim report' of a Phase $1 / 2 \mathrm{a}$ trial (18). The vaccine was tested at two doses $\left(5 \times 10^{10}\right.$ and $1 \times 10^{11}$ viral particles) that were given i.m. either once (day 0 only) or twice (days 0 and 56) to healthy adults aged $18-55(n=402)$ or $>65(n=394)$. Safety data were generally unexceptional, although two SAEs were reported and deemed, after investigation, to be either not vaccine-related or not problematic (a high fever that was resolved). Antibody immunogenicity was measured by S-protein ELISA, with data reported as Units/ml and an $\mathrm{RV} \mathrm{NAb}$ assay with an $\mathrm{IC}_{50}$ endpoint. T-cell responses to the S-protein were measured by ICS, and cytokine release profiles were used to gauge Th1 versus Th2 bias. The paper should be consulted for data on the multiple individual sub-groups. Here, we will summarize what was reported for the initial Phase 3 trial regimen, a single dose of $5 \times 10^{10}$ virus particles (Table 4). Moreover, although the two-dose groups are mentioned in the paper, no data were presented for the antibody and T-cell responses to the second dose. And only a small subset of some one-dose groups were included in several immunogenicity analyses. For the Phase 3 regimen, the GMT anti-S-protein ELISA values on day 29 were 528 and 507 Units for 15 of the younger and older volunteers, respectively. The corresponding $\mathrm{NAb}$ GMT IC 50 titers were 214 and 196, although some of the samples were said to need re-assaying and additional data from a PV NAb assay are reportedly pending. The weak T-cell response data show the expected Th1 bias. The ICS percentages of CD4+ and CD8+ T-cells expressing IFN-gamma and IL-2 at day 15 for the Phase 3 regimen were $0.08 \%$ and $0.07 \%$, respectively for the younger adults, and $0.36 \%$ and $0.05 \%$ for the older group (with large confidence intervals). The T-cell response rate varied depending on the sub-group and assay, and was anything from $33 \%$ to $100 \%$, although given the low number of samples in many cases the meaning of these data are not clear (18). Although the Phase 3 trial of the one-dose regimen is still ongoing, Janssen has initiated a second efficacy trial, in this case involving two doses of $5 \times 10^{10}$ virus particles given at weeks 0 and 8 . As noted above, this regimen evoked stronger and more sustained antibody responses than a single dose when evaluated in rhesus macaques (5).

Several weeks after the Russian Government approved the widespread use an adenovirus-vector based vaccine, GamCOVID-Vac, a report appeared on how it had performed in Phase $1 / 2$ trials (28). The vaccine involves the sequential delivery of rAd5 and rAd26 vectors that each express a fulllength S-protein, which are given intramuscularly at $1 \times 10^{11}$ particles per dose. Two sub-trials, each involving 38 volunteers aged 18-60, compared frozen/thawed (Gam-COVIDVac), or lyophilized/reconstituted (Gam-COVID-Vac-Lyo) vaccine formulations, which performed similarly (GamCOVID-Vac was chosen for widespread use on convenience grounds). In the combination trial $(n=20)$, the first dose was rAd26 on day 0 followed by rAd5 on day 21 . Smaller subgroups $(n=9)$ received only rAd5 or only rAd26. Phase 2 trials began a mere 5 days after Phase 1 ended, based on a successful interim safety assessment. Safety studies over 42 days (maximum) revealed nothing other than the generally mild reactions reported in other Ad-vector studies. Immunogenicity assessments involved determining endpoint titers in antiRBD and antiS1 IgG ELISAs and in an RV NAb assay, at weekly intervals. T-cell response data were derived from an INF-gamma ELISPOT and CD4+ and CD8+ T-cell proliferation assays. Anti-rAd5 antibodies were also measured to assess the possible influence of pre-existing immunity. AntiRBD endpoint titers peaked at $\sim 2000$ by day 21 in the singlevaccine groups, and were boosted to $10,000-15,000$ in the combination vaccine groups by day 42 . On day 42 , the anti-S1 GM endpoint titer in the Phase 2 trial combination group was 53,006 . NAb $\mathrm{CPE}_{67}$ titers at on day 28 in the single vaccine groups were in the range 5-10, but rose to GM values of 45.9549.25 by day 42 in the combination groups. The authors themselves note that these titers are lower than were seen in the AstraZeneca/Oxford ChAdOx1 and mRNA vaccine trials, a difference to which the different measurements of NAb titers $\left(\mathrm{ID}_{50}\right.$ versus $\mathrm{CPE}_{67}$ ) may contribute (see Table 4). Cell-mediated immunity was measured via a T-cell proliferation assay that is rarely used in the trials of the other vaccines reviewed here. Proliferative responses were detected in all participants but seem weak in magnitude and were not boosted by the second dose. On day 28 , after the boosting immunization, median T-cell proliferation values were $2 \cdot 5 \%$ vs. $1.3 \%$ for $\mathrm{CD} 4+$ and $1.3 \%$ vs. $1.1 \%$ for CD8+ cells in the groups receiving the frozen and lyophilized formulations, respectively. INF-gamma ELISPOT data were presented only as fold-increase from baseline values, so cannot be compared 
with other studies. However, there was again no boosting effect of the second immunization. A Phase 3 trial of the GamCOVID-Vac combination vaccine began on August 26, and is planned to involve 40,000 volunteers of various ages and risk groups (28).

\section{mRNA vaccines}

The Phase 1 trial of the Moderna mRNA-1273 vaccine involved 45 volunteers in three dosing groups who were given 25,100 or $250 \mu \mathrm{g}$ of the immunogen by the i.m. route on days 1 and 29 (19). Antibody immunogenicity was dose-dependent and much stronger after the second dose than the first. AntiS-protein GM endpoint titers in the $100 \mu \mathrm{g}$ group on day 57 (28 days after the second dose) were 782,000, while the corresponding anti-RBD endpoint titers were $\sim 30,000$. Most of the NAb data were derived from a PV assay; on day 43, the $\mathrm{GM} \mathrm{ID}_{50}$ titer for the $100 \mu \mathrm{g}$ group was 344 . An RV assay was also used on a subset of day 43 samples. The resulting $\mathrm{ID}_{80}$ titers were 654 for the $100 \mu \mathrm{g}$ group. Note that these are not $\mathrm{ID}_{50}$ values, which would be higher numbers. No detailed data on the longevity of the antibody responses were reported, but inspection of the graphs suggest that the antibody titers on a downward trend at the day 57 time point compared to days 36 and 43 . T cell responses were measured only by $\mathrm{CFC}$, and no data on their magnitude was reported. For both vaccine dose groups, the peptide pools activated specific Th1 responses from $<0.3 \%$ of the CD4 $+\mathrm{T}$ cells, and no Th2 responses were detectable. CD8+ T cell activity was, at most, minimal (19). In an extension of the trial that involved older adults (56-70 and over 71), the magnitudes of the anti-S-protein, anti-RBD and NAb responses to the two-dose regimens $(25 \mu \mathrm{g}$ or $100 \mu \mathrm{g})$ were similar to those reported for the 18-55 age groups (20) (Table 4). The $100 \mu \mathrm{g}$, two dose regimen was chosen for the Phase 3 studies that began in the USA during August 2020.

The Pfizer/BioNtech consortium has conducted three Phase 1 trials of lipid nanoparticle-encapsulated mRNAs that eventually led to the selection of the clinical candidate for now ongoing Phase $2 / 3$ studies (25-27). In the first trial, the BNT162b1 mRNA expressing a soluble, trimerized version of the RBD was given at two doses (10 $\mu \mathrm{g}$ and $30 \mu \mathrm{g})$ on days 1 and 21 to groups of 12 participants, and once at $100 \mu \mathrm{g}$ on day 1 to a third group of 12 . There were also 9 placebo recipients (25). Immunogenicity was assessed by anti-RBD $(25,26)$ or anti-S1 (27) binding Abs on days 7, 21, 28 and 35, although the data were reported in a non-traditional format that does not allow for cross-study comparison (25-27). All recipients in the two lower dose groups developed anti-RBD antibodies by day 21 that were boosted $\sim 10-20$-fold by the second immunization when measured on day 28 and unchanged by the end of the study on day 35 . The $30 \mu \mathrm{g}$ group was more immunogenic than $10 \mu \mathrm{g}$ by $\sim 3$-fold. The pattern of the NAb data was similar, although fewer time points were studied. In all three groups, the NAb responses to the initial immunization were low, but were boosted by the second dose. On day 28, the GM $\mathrm{ID}_{50}$ values in an RV assay for the 10 and $30 \mu \mathrm{g}$ groups were 168 and 267, respectively (25).

A second Phase 1 trial, conducted in Germany, also explored dosing regimens (26). Multiple doses of BNT162b1 mRNA, in the range 1-50 $\mu \mathrm{g}$, were tested, as were single doses and a prime-boost protocol involving two doses on days 0 and 21. Overall, and as expected, the immunogenicity data were comparable to what was seen in the first trial. Higher immunogen doses and the prime-boost format were associated with stronger responses, as expected. The anti-RBD ELISA data were again presented in a non-traditional format. After the second dose, NAb ID ID $_{5 M}$ titers in the higher dose groups were 578 in a RV assay and $\sim 3100$ in a PV assay. In an additional analysis, selected sera were tested in the PV-NAb assay against RBD and S-protein sequence variants (including the D614G change); no significant sensitivity differences were observed. T-cell responses were measured by a modified ELISPOT in which either CD4+ or CD8+ T cells were depleted from the effector population, or by CFC. An unpublished 'normalization' method was applied to enable direct comparison of spot counts/strength of response to anti-CD3 stimulation between individuals. Because PBMC were separated into either CD4+ or CD8+ subpopulations in the ELISPOT assay, no direct comparison can be made with ELISPOT data on the other vaccines reviewed here due to differences in methodology. CD4+ and CD8+ T-cell responses were analyzed immediately before vaccination and then on day 29 , i.e., 7 days after the booster immunization. The magnitudes of both T-cell responses were dose-dependent. At the highest dose, the majority of participants had T-cell responses $>1500 \mathrm{SFC} / 10^{6}$ cells. The magnitudes of the CD4+ and CD8+ responses were comparable. Approximately equal proportions of the $\mathrm{CD} 4+$ responders fell into groups with $<500,501-1500$ and $>1500$ $\mathrm{SFC} / 10^{6}$ cells. Cytokine secretion profiles showed that CD4+ $\mathrm{T}$ cells producing only IL-2 were the most abundant subset, while IL-4 release was minimal. This pattern is of potential concern, as CD4+ cells secreting IL-2 can polarize CD4+ T cells toward the Th2 phenotype that may be associated with VAERD (34-30=6). The responding CD8+ T cells mostly produced IFN-gamma (26).

The third Pfizer/BioNTech Phase 1 trial compared the BNT162b1 RBD-based construct with BNT162b2, an mRNA expressing a full-length, membrane-anchored S-protein (27). The two constructs were comparably immunogenic but BNT162b2 was associated with lower reactogenicity levels. Accordingly, BNT162b2 at a $30 \mu \mathrm{g}$ dose was selected to progress into Phase $2 / 3$ trials. The Phase 1 trial had two principal sub-components, involving adults aged 18-55 and ones aged 65-85. For each of the two mRNAs, 3 or 4 different doses (10, 
$20,30 \mu \mathrm{g}$ and in one case $100 \mu \mathrm{g}$ of mRNA, plus placebo) were tested in a two-immunization protocol (days 0, 21), so the 195 participants were split among 13 different groups in all. Here, we list the immunogenicity data only for the clinical candidate (BNT162b2, $30 \mu \mathrm{g}$ ), on day 28. NAb ID 50 GM titers in a RV assay were 361 and 149 for the 18-55 and 65-85 age groups respectively, while the corresponding GM antibody endpoints to the S1 protein in a Luminex assay were 9136 and 7985 (see also Table 4). Thus, for the clinical candidate, the NAb titers for the older group were $41 \%$ of those in their younger counterparts. Visual inspection of other antibody data sets suggests that the age-related reduction is generally $\sim 2-3$ fold, a decline that is perhaps meaningful but not catastrophic. No longer term antibody data and no information on T-cell responses were presented (27). The BNT162b2 vaccine candidate is now in Phase 3 trials in the USA and Europe, which involve a 2- dose regimen.

The Curevac CVnCoV mRNA vaccine was tested in 231 German adults aged 18-60, who were given different vaccine doses $(2-12 \mu \mathrm{g})$ twice, on days 0 and 28 (32). Moderate, dosedependent side effects were reported. Anti-S protein and antiRBD median endpoint titers on day 43 were moderately dosedependent and highest for the 12- $\mu$ g group (5463 and 1007, respectively). The median $\mathrm{CPE}_{50} \mathrm{NAb}$ titer measured in an RV assay at this time was 113 . No T-cell response data were presented. The $12-\mu \mathrm{g}$ dose was chosen for a Phase $2 \mathrm{~b} / 3$ trial (32).

\section{Recombinant protein vaccines}

The first report on how a recombinant S-protein performs in humans described the Novavax NVX-CoV2373 vaccine candidate (21). The immunogen is an insect cell-derived soluble Sprotein. When mixed with detergent, 5 or 6 S-proteins become attached non-covalently via their bases to the resulting micelles (63). This component of the immunogen was co-administered with Matrix-M adjuvant. Two formulations $(5 \mu \mathrm{g}$ and $25 \mu \mathrm{g}$ of S-protein) were tested in 106 people with or without adjuvant, in a two-dose regimen on days 0 and 21 . In the absence of adjuvant, antibody responses were, as expected, very weak, while the 5 - and $25-\mu \mathrm{g}$ doses performed comparably when the adjuvant was present. Anti-S-protein ELISA data were presented as Units, which again prevents cross-study comparison. The highest values recorded, on day 35 , were 63,160 . NAbs were measured in an RV assay and reported as $\mathrm{ID}_{>99}$ values. Here, the peak GM values were 3906 and 3305 for the 5 and $25 \mu \mathrm{g}$ groups, respectively, on day 35. As noted above when discussing the corresponding macaque experiment, when $\mathrm{NAb}$ data are presented as $\mathrm{ID}_{>99}$ or $\mathrm{CPE}_{100}$ values the reported numbers are likely to be several-fold lower than the more commonly used $\mathrm{ID}_{50}$ values. $\mathrm{CFC}$ was used to measure CD4+ T-cell responses at days 0 and 28, but in only 4 participants per group. There were no responses in the placebo or protein with no-adjuvant recipients, but $\mathrm{CD} 4+$
$\mathrm{T}$ cell signals could be measured in the adjuvanted protein groups at day 28 , with two protein doses inducing similar but moderate responses. Both Th1 and Th2 cytokines were released although the Th1 signals were more consistent, particularly at the lower protein dose (21). A Phase 3 trial of the Novavax vaccine began in the UK in September 2020, and its U.S. counterpart is scheduled to commence in December 2020.

The CoVLP vaccine from Medicago Inc. and McGill University is based on a stabilized S-protein engrafted to an influenza HA TM/CT region. These constructs, expressed in the plant cells, self-assemble into virus-like particles (VLPs) (31). In a Phase 1 study, the VLPs were administered without adjuvant or in either AS03 (GSK) or CpG 1018 (Dynavax) adjuvants, on days 0 and 21 , at doses of 3.75, 7.5 or $15 \mu \mathrm{g}$. The safety profile was unexceptional. Antibody responses were assessed by S-protein ELISA and in RV and PV NAb assays. The responses in the no-adjuvant group were, as expected, weak. The three dosing groups behaved fairly similarly; the lowestdose responses were at least as high as the others. The AS03 adjuvant consistently out-performed CpG 1018 by 10-50 fold in various groups at different times, which is a useful result with more general implications. On day $42, \mathrm{GM} \mathrm{EC}_{50}$ anti-S titers in the AS03 groups were $\sim 300,000$; NAb GM ID 50 values were $\sim 2200$ in the PV assay and $\sim 630$ in the RV assay (responses after the first dose only were very much weaker). Tcell responses were assessed by IFN-gamma and IL-4 ELISPOT assays and were again strongest in the AS03 groups (the differential vs CpG 1018 was greater for IFN-gamma than IL-4). The highest IFN-gamma signal (AS03, day 42) was 500 SFU per million cells, and $\sim 400$ for IL-4. The lowest dose $(3.75 \mu \mathrm{g})$ group with AS03 will proceed into additional clinical trials involving a two immunizations regime (31).

Taken together, and with caveats about comparing data from different studies, two features of the binding-antibody and NAb data stand out (Table 4). The seemingly strongest responses were induced by the NVX-CoV2373 adjuvanted recombinant S-protein. This judgement takes into account the presentation of $\mathrm{ID}_{>99}$ values, rather than the more commonly used $\mathrm{ID}_{50}$ titers (21). The relationship between $\mathrm{ID}_{>99}$ and $\mathrm{ID}_{50}$ values depends on the shape of the titration curve, but ID $_{>99}$ are by necessity lower, often $>10$-fold (Fig. 3). The superior immunogenicity of the recombinant S-protein mirrors its performance in macaques (Table 2$)(9,10)$. The second conclusion we can draw is that binding antibody and NAb responses to the single dose adenovirus vector vaccines are quite weak, although a second dose does improve their performance, as judged by the limited dataset available (Table 4) $(16,18,23,24)$. The T-cell response data are too limited, and the protocols used too variable, for us to draw any conclusions about relative immunogenicity. 


\section{Vaccine efficacy, as reported in press releases}

The press releases referred to below are all archived on the websites of the relevant institutions, and should be consulted for additional details or the precise language used. The first indications of vaccine efficacy came from a Pfizer/BioNTech release issued on 11/9/20. At that point, the companies had accumulated data from 94 COVID-19 cases during the BNT162b2 Phase 3 trial in which 38,955 volunteers had been fully vaccinated (7 days after the second dose). Although there was no breakdown of the 94 cases by vaccine versus placebo, the efficacy level was stated to be "above $90 \%$ ". Two linked releases from the same group on $11 / 18 / 20$ and $11 / 20 / 20$ provided additional information based on over 41,135 fully vaccinated trial participants. By then, the number of cases had reached 170 that were now broken down into 162 placebo recipients versus 8 given the vaccine, leading to an efficacy estimate of $95 \%$. High-level efficacy was reported for all demographic groups, including adults over 65 . In addition, it was announced that 10 severe COVID-19 cases had been documented, of which 9 were in the placebo group, an early although inconclusive indication that preventing severe disease might be possible.

Within about a day of the initial Pfizer/BioNTech release, one was issued by the Russian Direct Investment Fund and The Gamalaya National Center concerning their Sputnik V vaccine (11/11/20). It reported that 16,000 trial participants had received both vaccine doses; with 20 confirmed symptomatic cases and a calculated efficacy of $92 \%$. No vaccine versus placebo breakdown was provided. It was also stated that the number of COVID-19 cases identified in 10,000 more vaccine recipients who were not enrolled in clinical trials confirmed that vaccine efficacy was over $90 \%$. On $11 / 24 / 20$, a second press announcement on Sputnik V reported vaccine efficacy of $91.4 \%$ based on 39 COVID-19 cases among 18,794 fully vaccinated volunteers. Of these cases, 8 occurred in 14,095 vaccinated volunteers, while 31 were in 4,699 placebo recipients. The press release also mentioned that vaccine efficacy was over $95 \%$ when an analysis was performed at a later time point (21 days after the second dose, as opposed to 7 days), but no additional details were given.

Moderna issued its first press release on mRNA-1273 efficacy on 11/16/20. In the COVE trial of over 30,000 volunteers, 95 symptomatic cases had been documented, of which 90 were in the placebo group. Vaccine efficacy was reported to be $94.5 \%$. An additional analysis showed that all 11 cases of severe COVID-19 were in the placebo group. Consistent efficacy was seen in all demographic and age groups, although no details were reported. A further announcement on 11/30/20 reported that 196 symptomatic cases had now accrued in the trial, with 185 of them being in the placebo group. Vaccine efficacy was accordingly stated to be $94.1 \%$. Furthermore, all 30 cases of severe COVID-19, including one death, were in the placebo group, which strengthens the evidence that this vaccine also prevents serious disease. This second press release again stated that efficacy was consistent across age, race, ethnicity and gender demographics.

A press release was issued by AstraZeneca on $11 / 23 / 20$, reporting on the company's AZD1222 (ChAdOx1) vaccine. The information it contained was based on two trials in the UK and Brazil, and could be considered quite confusing (https://www.wired.com/story/the-astrazeneca-covidvaccine-data-isnt-up-to-snuff/). Some clarifications emerged in subsequent media reporting and oral statements. The summary below reflects what is known at the time of writing. In total, 131 COVID-19 cases occurred in the trials, but their distribution was not broken down either by trial or vaccine vs. placebo. One dosing regimen involving $2,741 \mathrm{UK}$ volunteers was stated to confer $90 \%$ efficacy. It involved a half dose of vaccine followed by a full dose at least one month later, a regimen that was the result of an apparent error in dose calculations. In contrast, the trials involving the originally intended protocol of two full doses yielded an efficacy of $62 \%$ from 8,895 vaccinated volunteers. Combining all the trials, which may or may not be appropriate for regulatory approval, led to a stated "average efficacy" of $70 \%$. It was also reported that no hospitalizations or severe cases of COVID-19 occurred among vaccine recipients, which is presumably a reference only to the unstated number who became infected. Additional data from an ongoing phase 3 trial in the USA, and from a new one that may be initiated in the UK, may eventually clarify where this vaccine stands on the efficacy spectrum.

\section{Summary and conclusions}

Although the press releases summarized above are sometimes confusing and generally contain less information than is desirable, together they imply that high-level protection against symptomatic SARS-CoV-2 infection can be achieved by vaccination. Moreover, there are early indications that vaccines will also be able to protect against severe COVID-19 disease.

Whether all the first-generation vaccines can protect at efficacy levels of around $90 \%$ will require more data to answer, including from Phase 3 trials that are yet to report endpoints. It should also be noted that differences in apparent efficacy may at least in part depend on how symptomatic infections are documented in the different trials, which seems to vary. In some trials (e.g., Pfizer/BioNTech and Moderna), infected people are identified when they report to trial sites with symptoms and are RNA-tested, in another (AstraZeneca) participants are RNA-tested weekly and asked about symptoms. Whether these endpoints are equivalent is not yet clear. It is also unknown whether the vaccine protects against asymptomatic infection, which is important if asymptomatic infected 
vaccine recipients are still capable of transmitting virus to other people. While this scenario cannot be dismissed, we think it is perhaps unlikely to be common. As we discussed above, several of the vaccines provide what seems to be sterilizing immunity to at least some of the immunized macaques, which represents protection against asymptomatic infection. While extrapolation from NHPs to humans is also fraught with uncertainties, we are now seeing solid signs of protection in both species that increase the weight that can be put on the monkey models.

We await information on CoPs for a human SARS-CoV-2 vaccine, although it does seem increasingly likely that they are antibody-associated. Assuming that serum NAb titers are indeed the principal CoP, we do not yet know what a highly protective minimum NAb titer will be. In an earlier review, we suggested that NAb titers in the low hundreds might be sufficient for protection (34). In one study, when 122 Seattle seamen sailed seawards, 104 of them had become SARS-CoV2 RNA-positive from a single source of virus by the time their boat returned to port 18 days later. However, three sailors who had NAb responses at the time of departure were not reinfected while at sea. Their serum PV ID ${ }_{50}$ NAb titers were 174, 161 and 3082 (71). Thus, while certainly far from definitive, this study further suggests that a protective serum NAb titer may lie in the low hundreds. The peak NAb responses to many, but not all, of the leading vaccines exceed that mark (Table 4). Once completed and fully analyzed, the ongoing efficacy trials should yield information on the threshold $\mathrm{NAb}$ titers giving certain percentages of protection from infection or disease. Again, however, the use of NAb assays with different properties and sensitivities is likely to blur comparisons of the datasets generated in the various trials $(34,51)$. Now that robust, reliable and potentially high-throughput assays are available, perhaps some of these uncertainties can be resolved in centralized testing programs under national or even international coordination $(72,73)$.

One caveat about the press releases is that all the efficacy data so far are derived from analyses conducted within the first few weeks to months after completion of the vaccination protocol. The duration of vaccine-induced immunity is unknown. We also know little about the role of T-cells in protection, and almost no information is available about mucosal immunity or immune memory. Memory $\mathrm{B}$ and $\mathrm{T}$ cells will be relevant to sustained protection by the vaccines. Significant and highly encouraging information is now emerging on the extent of immunological memory and the maintenance of NAb responses after $\sim 6$-months of SARSCoV-2 infection $(54,55)$. Similar studies will need to be performed on vaccine recipients after sufficient time has elapsed. The magnitude of the initial NAb responses to the vaccines may be relevant in this context. Plasma antibody titers can be expected to diminish over time, and at some point, they may drop below a protective threshold. The stronger the initial, peak response, the longer that process will take. Time will tell. Nonetheless, it is hard to argue against the long-term benefits of a strong initial NAb response when it comes to conferring protection during the first year after vaccination, which may be particularly critical in curtailing the COVID-19 pandemic.

Next-generation immunogens now at the pre-clinical stage of development may play a role if some of the leading vaccines are less effective than is hoped $(34,35,45)$. Combining vaccines in prime-boost formats may provide superior and longer lasting protection than single agents (34). Nonetheless, there are now highly encouraging signs for the control of the pandemic if and when multiple SARS-CoV-2 vaccines can be rolled out en masse during 2021.

\section{REFERENCES AND NOTES}

1. Q. Gao, L. Bao, H. Mao, L. Wang, K. Xu, M. Yang, Y. Li, L. Zhu, N. Wang, Z. Lv, H. Gao, X. Ge, B. Kan, Y. Hu, J. Liu, F. Cai, D. Jiang, Y. Yin, C. Qin, J. Li, X. Gong, X. Lou, W. Shi, D. Wu, H. Zhang, L. Zhu, W. Deng, Y. Li, J. Lu, C. Li, X. Wang, W. Yin, Y. Zhang, C. Qin, Development of an inactivated vaccine candidate for SARS-CoV-2. Science 369, 77-81 (2020). doi:10.1126/science.abc1932 Medline

2. H. Wang, Y. Zhang, B. Huang, W. Deng, Y. Quan, W. Wang, W. Xu, Y. Zhao, N. Li, J. Zhang, H. Liang, L. Bao, Y. Xu, L. Ding, W. Zhou, H. Gao, J. Liu, P. Niu, L. Zhao, W. Zhen, H. Fu, S. Yu, Z. Zhang, G. Xu, C. Li, Z. Lou, M. Xu, C. Qin, G. Wu, G. F. Gao, W. Tan, X. Yang, Development of an inactivated vaccine candidate, BBIBP-CorV, with potent protection against SARS-CoV-2. Cell 182, 713-721.e9 (2020). doi:10.1016/i.cell.2020.06.008 Medline

3. N. van Doremalen, T. Lambe, A. Spencer, S. Belij-Rammerstorfer, J. N. Purushotham, J. R. Port, V. A. Avanzato, T. Bushmaker, A. Flaxman, M. Ulaszewska, F. Feldmann, E. R. Allen, H. Sharpe, J. Schulz, M. Holbrook, A. Okumura, K. Meade-White, L. Pérez-Pérez, N. J. Edwards, D. Wright, C. Bissett, C. Gilbride, B. N. Williamson, R. Rosenke, D. Long, A. Ishwarbhai, R. Kailath, L. Rose, S. Morris, C. Powers, J. Lovaglio, P. W. Hanley, D. Scott, G. Saturday, E. de Wit, S. C. Gilbert, V. J. Munster, ChAdOx1 nCoV-19 vaccine prevents SARS-CoV-2 pneumonia in rhesus macaques. Nature 586, 578-582 (2020). doi:10.1038/s41586-020-2608-y Medline

4. N. B. Mercado, R. Zahn, F. Wegmann, C. Loos, A. Chandrashekar, J. Yu, J. Liu, L. Peter, K. McMahan, L. H. Tostanoski, X. He, D. R. Martinez, L. Rutten, R. Bos, D. van Manen, J. Vellinga, J. Custers, J. P. Langedijk, T. Kwaks, M. J. G. Bakkers, D. Zuijdgeest, S. K. Rosendahl Huber, C. Atyeo, S. Fischinger, J. S. Burke, J. Feldman, B. M. Hauser, T. M. Caradonna, E. A. Bondzie, G. Dagotto, M. S. Gebre, E. Hoffman, C. Jacob-Dolan, M. Kirilova, Z. Li, Z. Lin, S. H. Mahrokhian, L. F. Maxfield, F. Nampanya, R. Nityanandam, J. P. Nkolola, S. Patel, J. D. Ventura, K. Verrington, H. Wan, L. Pessaint, A. Van Ry, K. Blade, A. Strasbaugh, M. Cabus, R. Brown, A. Cook, S. Zouantchangadou, E. Teow, H. Andersen, M. G. Lewis, Y. Cai, B. Chen, A. G. Schmidt, R. K. Reeves, R. S. Baric, D. A. Lauffenburger, G. Alter, P. Stoffels, M. Mammen, J. Van Hoof, H. Schuitemaker, D. H. Barouch, Single-shot Ad26 vaccine protects against SARS-CoV-2 in rhesus macaques. Nature 586, 583-588 (2020). doi:10.1038/s41586-020-2607-z Medline

5. L. Solforosi, H. Kuipers, S. K. Rosendahl Huber, J. E.M. van der Lubbe, L. Dekking, D. N. Czapska-Casey, A. Izquierdo Gil, M. R. M. Baert, J. Drijver, J. Vaneman, E. van Huizen, Y. Choi, J. Vreugdenhil, T. J. Dalebout, S. K. Myeni, M. Kikkert, E. J. Snijder, D. H. Barouch, G. Koopman, P. Mooij, W. M. J. M. Bogers, L. Muchene, J. T. B. M. Tolboom, R. Roozendaal, H. Schuitemaker, F. Wegmann, R. C. Zahn, Immunogenicity of one- and two-dose regimens of the Ad26.COV2.S COVID-19 vaccine candidate in adult and aged rhesus macaques. bioRxiv 2020.11.17.368258 [Preprint] 17 Nov 2020; 10.1101/2020.11.17.368258

6. J. Yu, L. H. Tostanoski, L. Peter, N. B. Mercado, K. McMahan, S. H. Mahrokhian, J. P. Nkolola, J. Liu, Z. Li, A. Chandrashekar, D. R. Martinez, C. Loos, C. Atyeo, S. Fischinger, J. S. Burke, M. D. Slein, Y. Chen, A. Zuiani, F. J. N. Lelis, M. Travers, S. Habibi, L. Pessaint, A. Van Ry, K. Blade, R. Brown, A. Cook, B. Finneyfrock, A. 
Dodson, E. Teow, J. Velasco, R. Zahn, F. Wegmann, E. A. Bondzie, G. Dagotto, M. S. Gebre, X. He, C. Jacob-Dolan, M. Kirilova, N. Kordana, Z. Lin, L. F. Maxfield, F. Nampanya, R. Nityanandam, J. D. Ventura, H. Wan, Y. Cai, B. Chen, A. G. Schmidt, D. R. Wesemann, R. S. Baric, G. Alter, H. Andersen, M. G. Lewis, D. H. Barouch, DNA vaccine protection against SARS-CoV-2 in rhesus macaques. Science 369 , 806-811 (2020). doi:10.1126/science.abc6284 Medline

7. A. Patel, J. Walters, E. L. Reuschel, K. Schultheis, E. Parzych, E. N. Gary, I. Maricic, M. Purwar, Z. Eblimit, S. N. Walker, D. Guimet, P. Bhojnagarwala, A. Doan, Z. Xu, D. Elwood, S. M. Reeder, L. Pessaint, K. Y. Kim, A. Cook, N. Chokkalingam, B. Finneyfrock, E. Tello-Ruiz, A. Dodson, J. Choi, A. Generotti, J. Harrison, N. J. Tursi, V. M. Andrade, Y. Dia, F. T. Zaidi, H. Andersen, H. G. Lewis, K. Muthumani, J. J. Kim, D. W. Kulp, L.M, Humeau, S. Ramos, T.R.F. Smith, D.B. Weiner, K.E. Broderick, Intradermal-delivered DNA vaccine provides anamnestic protection in a rhesus macaque SARS-CoV-2 challenge model. bioRxiv (2020). $10.1101 / 2020.07 .28 .225649$

8. K. S. Corbett, B. Flynn, K. E. Foulds, J. R. Francica, S. Boyoglu-Barnum, A. P. Werner, B. Flach, S. O'Connell, K. W. Bock, M. Minai, B. M. Nagata, H. Andersen, D. R. Martinez, A. T. Noe, N. Douek, M. M. Donaldson, N. N. Nji, G. S. Alvarado, D. K. Edwards, D. R. Flebbe, E. Lamb, N. A. Doria-Rose, B. C. Lin, M. K. Louder, S. O'Dell, S. D. Schmidt, E. Phung, L. A. Chang, C. Yap, J. M. Todd, L. Pessaint, A. Van Ry, S. Browne, J. Greenhouse, T. Putman-Taylor, A. Strasbaugh, T. A. Campbell, A. Cook, A. Dodson, K. Steingrebe, W. Shi, Y. Zhang, O. M. Abiona, L. Wang, A. Pegu, E. S. Yang, K. Leung, T. Zhou, I. T. Teng, A. Widge, I. Gordon, L. Novik, R. A. Gillespie, R. J. Loomis, J. I. Moliva, G. Stewart-Jones, S. Himansu, W. P. Kong, M. C. Nason, K. M. Morabito, T. J. Ruckwardt, J. E. Ledgerwood, M. R. Gaudinski, P. D. Kwong, J. R. Mascola, A. Carfi, M. G. Lewis, R. S. Baric, A. McDermott, I. N. Moore, N. J. Sullivan, M. Roederer, R. A. Seder, B. S. Graham, Evaluation of the mRNA-1273 vaccine against SARS-CoV-2 in nonhuman primates. N. Engl. J. Med. 383, 1544-1555 (2020). doi:10.1056/NEJMoa2024671 Medline

9. J. H. Tian, N. Patel, R. Haupt, H. Zhou, S. Weston, H. Hammond, J. Lague, A. D. Portnoff, J. Norton, M. Guebre-Xabier, B. Zhou, K. Jacobson, S. Maciejewski, R. Khatoon, M. Wisniewska, W. Moffitt, S. Kluepfel-Stahl, B. Ekechukwu, J. Papin, S. Boddapati, C. J. Wong, P. A. Piedra, M. B. Frieman, M. J. Massare, L. Fries, K. L. Bengtsson, L. Stertman, L. Ellingsworth, G. Glenn, G. Smith, SARS-CoV-2 spike glycoprotein vaccine candidate NVX-CoV3273 elicits immunogenicity in baboons and protection in mice. bioRxiv (2020). 10.1101/2020.06.29.178509

10. M. Guebre-Xabier, N. Patel, J.-H. Tian, B. Zhou, S. Maciejewski, K. Lam, A. D. Portnoff, M. J. Massare, M. B. Frieman, P. A. Piedra, L. Ellingsworth, G. Glenn, G. Smith, NVX-CoV2373 vaccine protects cynomolgus macaque upper and lower airways against SARS-CoV-2 challenge. bioRxiv 38, 7892-7896 (2020). 10.1101/2020.08.18.256578 Medline

11. A. Vogel, I. Kanevsky, Y. Che, K. Swanson, A. Muik, M. Vormehr, L. Kranz, K. Walzer, S. Hein, A. Gueler, J. Loschko, M. Maddur, K. Tompkins, J. Cole, B. G. Lui, T. Ziegenhals, A. Plaschke, D. Eisel, S. Dany, S. Fesser, S. Erbar, F. Bates, D. Schneider, B. Jesionek, B. Saenger, A. K. Wallisch, Y. Feuchter, H. Junginger, S. Krumm, A. Heinen, P. Adams-Quack, J. Schlereth, C. Kroener, S. Hall-Ursone, K. Brasky, M. C. Griffor, S. Han, J. Lees, E. Mashalidis, P. Sahasrabudhe, C. Tan, D. Pavliakova, G. Singh, C. Fontes-Garfias, M. Pride, I. Scully, T. Ciolino, J. Obregon, M. Gazi, R. Carrion, K. Alfson, W. Kalina, D. Kaushal, P. Y. Shi, T. Klamp, C. Rosenbaum, A. Kuhn, O. Tuereci, P. Dormitzer, K. Jansen, U. Sahin, A prefusion SARS-CoV-2 spike RNA vaccine is highly immunogenic and prevents lung infection in non-human primates. bioRxiv (2020). 10.1101/2020.09.08.280818

12. J. G. Liang, D. Su, T.-Z. Song, Y. Zeng, W. Huang, J. Wu, R. Xu, P. Luo, X. Yang, X. Zhang, S. Luo, Y. Liang, X. Li, J. Huang, Q. Wang, X. Huang, Q. Xu, M. Luo, A. Huang, D. Luo, C. Zhao, F. Yang, J.-B. Han, Y.-T. Zheng, P. Liang, S-Trimer, a COVID-19 subunit vaccine candidate, induces protective immunity in nonhuman primates. bioRxiv (2020). 10.1101/2020.09.24.311027

13. K. V. Kalnin, T. Plitnik, M. Kishko, J. Zhang, D. Zhang, A. Beauvais, N. G. Anosova, T. Tibbitts, J. M. DiNapoli, P.-W. D. Huang, J. Huleatt, D. Vincent, K. Fries, S. Karve, R. Goldman, H. Gopani, A. Dias, K. Tran, M. Zacharia, X. Gu, L. Boeglin, S. Chivukula, R. Swearingen, V. Landolfi, T.-M. Fu, F. DeRosa, D. Casimiro, Immunogenicity of novel mRNA COVID-19 vaccine MRT5500 in mice and nonhuman primates. bioRxiv (2020). 10.1101/2020.10.14.337535

14. Y.-J. Zhang, G. Zeng, H.-X. Pan, C.-G. Li, B. Kan, Y.-L. Hu, H.-Y. Mao, Q.-Q. Xin, K. Chu, W.-X. Han, Z. Chen, R. Tang, W.-D. Yin, X. Chen, X.-J. Gong, C. Qin, Y.-S. Hu,
X.-Y. Liu, G.-L. Cui, C.-B. Jiang, H.-M. Zhang, J.-X. Li, M.-N. Yang, X.-J. Lian, Y. Song, J.-X. Lu, X.-X. Wang, M. Xu, Q. Gao, F.-C. Zhu, Immunogenicity and safety of a SARS-CoV-2 inactivated vaccine in healthy adults aged $18-59$ years: report of the randomized, double-blind, and placebo-controlled phase 2 clinical trial. medRxiv. 10.1101/2020.07.31.20161216. (2020).

15. S. Xia, Y. Zhang, Y. Wang, H. Wang, Y. Yang, G. F. Gao, W. Tan, G. Wu, M. Xu, Z. Lou, W. Huang, W. Xu, B. Huang, H. Wang, W. Wang, W. Zhang, N. Li, Z. Xie, L. Ding, W. You, Y. Zhao, X. Yang, Y. Liu, Q. Wang, L. Huang, Y. Yang, G. Xu, B. Luo, W. Wang, P. Liu, W. Guo, X. Yang, Safety and immunogenicity of an inactivated SARS-CoV-2 vaccine, BBIBP-CorV: a randomised, double-blind, placebo-controlled, phase 1/2 trial. Lancet Infect. Dis. S1473-3099(20)30831-8. (2020).

16. P. M. Folegatti, K. J. Ewer, P. K. Aley, B. Angus, S. Becker, S. Belij-Rammerstorfer, D. Bellamy, S. Bibi, M. Bittaye, E. A. Clutterbuck, C. Dold, S. N. Faust, A. Finn, A. L. Flaxman, B. Hallis, P. Heath, D. Jenkin, R. Lazarus, R. Makinson, A. M. Minassian, K. M. Pollock, M. Ramasamy, H. Robinson, M. Snape, R. Tarrant, M. Voysey, C. Green, A. D. Douglas, A. V. S. Hill, T. Lambe, S. C. Gilbert, A. J. Pollard; Oxford COVID Vaccine Trial Group, Safety and immunogenicity of the ChAdOx1 nCoV-19 vaccine against SARS-CoV-2: A preliminary report of a phase 1/2, single-blind, randomised controlled trial. Lancet 396, 467-478 (2020). doi:10.1016/S01406736(20)31604-4 Medline

17. M. N. Ramasamy, A. M. Minassian, K. J. Ewer, A. L. Flaxman, P. M. Folegatti, D. R. Owens, M. Voysey, P. K. Aley, B. Angus, G. Babbage, S. Belij-Rammerstorfer, L. Berry, S. Bibi, M. Bittaye, K. Cathie, H. Chappell, S. Charlton, P. Cicconi, E. A. Clutterbuck, R. Colin-Jones, C. Dold, K. R. W. Emary, S. Fedosyuk, M. Fuskova, D. Gbesemete, C. Green, B. Hallis, M. M. Hou, D. Jenkin, C. C. D. Joe, E. J. Kelly, S. Kerridge, A. M. Lawrie, A. Lelliott, M. N. Lwin, R. Makinson, N. G. Marchevsky, Y. Mujadidi, A. P. S. Munro, M. Pacurar, E. Plested, J. Rand, T. Rawlinson, S. Rhead, H. Robinson, A. J. Ritchie, A. L. Ross-Russell, S. Saich, N. Singh, C. C. Smith, M. D. Snape, R. Song, R. Tarrant, Y. Themistocleous, K. M. Thomas, T. L. Villafana, S. C. Warren, M. E. E. Watson, A. D. Douglas, A. V. S. Hill, T. Lambe, S. C. Gilbert, S. N. Faust, A. J. Pollard, O. C. V. T. Group, Safety and immunogenicity of ChAdOx1 $\mathrm{nCoV}-19$ vaccine administered in a prime-boost regimen in young and old adults (COV002): a single-blind, randomised, controlled, phase 2/3 trial. Lancet, S01406736(20)32466-1. (2020).

18. J. Sadoff, M. Le Gars, G. Shukarev, D. Heerwegh, C. Truyers, A. M. de Groot, J. Stoop, S. Tete, W. Van Damme, I. Leroux-Roels, P.-J. Berghmans, M. Kimmel, P. Van Damme, J. De Hoon, W. Smith, K. Stephenson, D. Barouch, S. De Rosa, K. Cohen, J. McElrath, E. Cormier, G. Scheper, J. Hendriks, F. Struyf, M. Douoguih, J. Van Hoof, H. Schuitemaker, Safety and immunogenicity of the Ad26.COV2.S COVID-19 vaccine candidate: interim results of a phase $1 / 2$ a, double-blind, randomized, placebo-controlled trial. medRxiv. 10.1101/2020.09.23.20199604. (2020).

19. L. A. Jackson, E. J. Anderson, N. G. Rouphael, P. C. Roberts, M. Makhene, R. N. Coler, M. P. McCullough, J. D. Chappell, M. R. Denison, L. J. Stevens, A. J. Pruijssers, A. McDermott, B. Flach, N. A. Doria-Rose, K. S. Corbett, K. M. Morabito, S. O'Dell, S. D. Schmidt, P. A. Swanson 2nd, M. Padilla, J. R. Mascola, K. M. Neuzil, H. Bennett, W. Sun, E. Peters, M. Makowski, J. Albert, K. Cross, W. Buchanan, R. Pikaart-Tautges, J. E. Ledgerwood, B. S. Graham, J. H. Beigel; for the mRNA-1273 Study Group, An mRNA Vaccine against SARS-CoV-2 - Preliminary Report. N. Engl. J. Med. 383, 1920-1931 (2020). 10.1056/NEJMoa2022483 Medline

20. E. J. Anderson, N. G. Rouphael, A. T. Widge, L. A. Jackson, P. C. Roberts, M. Makhene, J. D. Chappell, M. R. Denison, L. J. Stevens, A. J. Pruijssers, A. B. McDermott, B. Flach, B. C. Lin, N. A. Doria-Rose, S. O'Dell, S. D. Schmidt, K. S. Corbett, P. A. Swanson 2nd, M. Padilla, K. M. Neuzil, H. Bennett, B. Leav, M. Makowski, J. Albert, K. Cross, V. V. Edara, K. Floyd, M. S. Suthar, D. R. Martinez, R. Baric, W. Buchanan, C. J. Luke, V. K. Phadke, C. A. Rostad, J. E. Ledgerwood, B. S. Graham, J. H. Beigel; for the mRNA-1273 Study Group, Safety and immunogenicity of SARS-CoV-2 mRNA-1273 vaccine in older adults. N. Engl. J. Med. 383, 24272438 (2020). 10.1056/NEJMoa2028436 Medline

21. C. Keech, G. Albert, I. Cho, A. Robertson, P. Reed, S. Neal, J. S. Plested, M. Zhu, S. Cloney-Clark, H. Zhou, G. Smith, N. Patel, M. B. Frieman, R. E. Haupt, J. Logue, M. McGrath, S. Weston, P. A. Piedra, C. Desai, K. Callahan, M. Lewis, P. Price-Abbott, N. Formica, V. Shinde, L. Fries, J. D. Lickliter, P. Griffin, B. Wilkinson, G. M. Glenn, Phase 1-2 trial of a SARS-CoV-2 recombinant spike protein nanoparticle vaccine. N. Engl. J. Med. 383, 2320-2332 (2020). doi:10.1056/NEJMoa2026920 Medline 
22. S. Xia, K. Duan, Y. Zhang, D. Zhao, H. Zhang, Z. Xie, X. Li, C. Peng, Y. Zhang, W. Zhang, Y. Yang, W. Chen, X. Gao, W. You, X. Wang, Z. Wang, Z. Shi, Y. Wang, X. Yang, L. Zhang, L. Huang, Q. Wang, J. L. Y. Yang, J. Guo, W. Zhou, X. Wan, C. Wu, W. Wang, S. Huang, J. Du, Z. Meng, A. Pan, Z. Yuan, S. Shen, W. Guo, X. Yang, Effect of an inactivated vaccine against SARS-CoV-2 on safety and immunogenicity outcomes: Interim analysis of 2 randomized clinical trials. JAMA 324, 1-10 (2020). doi:10.1001/jama.2020.15543

23. F. C. Zhu, Y. H. Li, X. H. Guan, L. H. Hou, W. J. Wang, J. X. Li, S. P. Wu, B. S. Wang, Z. Wang, L. Wang, S. Y. Jia, H. D. Jiang, L. Wang, T. Jiang, Y. Hu, J. B. Gou, S. B. Xu, J. J. Xu, X. W. Wang, W. Wang, W. Chen, Safety, tolerability, and immunogenicity of a recombinant adenovirus type-5 vectored COVID-19 vaccine: A doseescalation, open-label, non-randomised, first-in-human trial. Lancet 395, 18451854 (2020). doi:10.1016/S0140-6736(20)31208-3 Medline

24. F. C. Zhu, X. H. Guan, Y. H. Li, J. Y. Huang, T. Jiang, L. H. Hou, J. X. Li, B. F. Yang, L. Wang, W. J. Wang, S. P. Wu, Z. Wang, X. H. Wu, J. J. Xu, Z. Zhang, S. Y. Jia, B. S. Wang, Y. Hu, J. J. Liu, J. Zhang, X. A. Qian, Q. Li, H. X. Pan, H. D. Jiang, P. Deng, J. B. Gou, X. W. Wang, X. H. Wang, W. Chen, Immunogenicity and safety of a recombinant adenovirus type-5-vectored COVID-19 vaccine in healthy adults aged 18 years or older: A randomised, double-blind, placebo-controlled, phase 2 trial. Lancet 396, 479-488 (2020). doi:10.1016/S0140-6736(20)31605-6 Medline

25. M. Mulligan, K. Lyke, N. Kitchin, J. Absalon, A. Gurtman, S. P. Lockhart, K. Neuzil, V. Raabe, R. Bailey, K. A. Swanson, P. Li, K. Koury, W. Kalina, D. Cooper, C. FonterGarfias, P.-Y. Shi, O. Tuereci, K. R. Tompkins, E. E. Walsh, R. Frenck, A. R. Falsey, P. R. Dormitzer, W. C. Gruber, U. C. Sahin, K. U. Jansen, Phase 1/2 study to describe the safety and immunogenicity of a COVID-19 RNA vaccine candidate (BNT162b1) in adults 18 to 55 years of age: Interim report. Nature $586,589-593$ (2020). doi:10.1038/s41586-020-2639-4 Medline

26. U. Sahin, A. Muik, E. Derhovanessian, I. Vogler, L. M. Kranz, M. Vormehr, A. Baum, K. Pascal, J. Quandt, D. Maurus, S. Brachtendorf, V. Lörks, J. Sikorski, R. Hilker, D. Becker, A.-K. Eller, J. Grützner, C. Boesler, C. Rosenbaum, M.-C. Kühnle, U. Luxemburger, A. Kemmer-Brück, D. Langer, M. Bexon, S. Bolte, K. Karikó, T. Palanche, B. Fischer, A. Schultz, P.-Y. Shi, C. Fontes-Garfias, J. L. Perez, K. A. Swanson, J. Loschko, I. L. Scully, M. Cutler, W. Kalina, C. A. Kyratsous, D. Cooper, P. R. Dormitzer, K. U. Jansen, Ö. Türeci, COVID-19 vaccine BNT162b1 elicits human antibody and $T_{H} 1 \mathrm{~T}$ cell responses. Nature 586, 594-599 (2020). doi:10.1038/s41586-020-2814-7 Medline

27. E. E. Walsh, R. W. Frenck Jr., A. R. Falsey, N. Kitchin, J. Absalon, A. Gurtman, S. Lockhart, K. Neuzil, M. J. Mulligan, R. Bailey, K. A. Swanson, P. Li, K. Koury, W. Kalina, D. Cooper, C. Fontes-Garfias, P. Y. Shi, Ö. Türeci, K. R. Tompkins, K. E. Lyke, V. Raabe, P. R. Dormitzer, K. U. Jansen, U. Şahin, W. C. Gruber, Safety and immunogenicity of two RNA-based COVID-19 vaccine candidates. N. Engl. J. Med. 383, 2439-2450 (2020). 10.1056/NEJMoa2027906 Medline

28. D. Y. Logunov, I. V. Dolzhikova, O. V. Zubkova, A. I. Tukhvatulin, D. V. Shcheblyakov, A. S. Dzharullaeva, D. M. Grousova, A. S. Erokhova, A. V. Kovyrshina, A. G. Botikov, F. M. Izhaeva, O. Popova, T. A. Ozharovskaya, I. B. Esmagambetov, I. A. Favorskaya, D. I. Zrelkin, D. V. Voronina, D. N. Shcherbinin, A. S. Semikhin, Y. V. Simakova, E. A. Tokarskaya, N. L. Lubenets, D. A. Egorova, M. M. Shmarov, N. A. Nikitenko, L. F. Morozova, E. A. Smolyarchuk, E. V. Kryukov, V. F. Babira, S. V. Borisevich, B. S. Naroditsky, A. L. Gintsburg, Safety and immunogenicity of an rAd26 and rAd5 vector-based heterologous prime-boost COVID-19 vaccine in two formulations: Two open, non-randomised phase 1/2 studies from Russia. Lancet 396, 887-897 (2020). doi:10.1016/S0140-6736(20)31866-3 Medline

29. J. Pu, Q. Yu, Z. Yin, Y. Zhang, X. Li, D. Li, H. Chen, R. Long, Z. Zhao, T. Mou, H. Zhao, S. Feng, Z. Xie, L. Wang, Z. He, Y. Liao, S. Fan, Q. Yin, R. Jiang, J. Wang, L. Zhang, J. Li, H. Zheng, P. Cui, G. Jiang, L. Guo, M. Xu, H. Yang, S. Lu, X. Wang, Y. Gao, X. Xu, L. Cai, J. Zhou, L. Yu, Z. Chen, C. Hong, D. Du, H. Zhao, Y. Li, K. Ma, Y. Ma, D. Liu, S. Yao, C. Li, Y. Che, L. Liu, Q. Li, An in-depth investigation of the safety and immunogenicity of an inactivated SARS-CoV-2 vaccine. medRxiv. 10.1101/2020.09.27.20189548. (2020).

30. Y. Che, X. Liu, Y. Pu, M. Zhou, Z. Zhao, R. Jiang, Z. Yin, M. Xu, Q. Yin, J. Wang, J. Pu, H. Zhao, Y. Zhang, L. Wang, Y. Jiang, J. Lei, Y. Zheng, Y. Liao, R. Long, L. Yu, P. Cui, H. Yang, Y. Zhang, J. Li, W. Chen, Z. He, K. Ma, C. Hong, D. Li, G. Jiang, D. Liu, X. Xu, S. Fan, C. Cheng, H. Zhao, J. Yang, Y. Li, Y. Zou, Y. Zhu, Y. Zhou, Y. Guo, T. Yang, H. Chen, Z. Xie, C. Li, Q. Li, Randomized, double-blinded and placebo-controlled phase II trial of an inactivated SARS-CoV-2 vaccine in healthy adults. Clin. Infect. Dis. ciaa1703 (2020). doi:10.1093/cid/ciaa1703 Medline

31. B. J. Ward, P. Gobeil, A. Séguin, J. Atkins, I. Boulay, P.-Y. Charbonneau, M. Couture, M.-A. D’Aoust, J. Dhaliwall, C. Finkle, K. Hager, A. Mahmood, A. Makarkov, M. Cheng, S. Pillet, P. Schimke, S. St-Martin, S. Trépanier, N. Landry, Phase 1 trial of a candidate recombinant virus-like particle vaccine for Covid-19 disease produced in plants. medRxiv 2020.11.04.20226282 [Preprint] 06 Nov 2020; $10.1101 / 2020.11 .04 .20226282$

32. P. Kremsner, P. Mann, J. Bosch, R. Fendel, J. J. Gabor, A. Kreidenweiss, A. Kroidl, I. Leroux-Roels, G. Leroux-Roels, C. Schindler, M. Schunk, T. P. Velavan, M. FotinMleczek, S. Müller, G. Quintini, O. Schönborn-Kellenberger, D. Vahrenhorst, T. Verstraeten, L. Walz, O.-O. Wolz, L. Oostvogels, Phase 1 Assessment of the safety and immunogenicity of an mRNA-lipid nanoparticle vaccine candidate against SARS-CoV-2 in human volunteers. medRxiv 2020.11.09.20228551 [Preprint] 09 Nov 2020; 10.1101/2020.11.09.20228551

33. M. Slaoui, M. Hepburn, Developing safe and effective COVID vaccines - Operation Warp Speed's strategy and approach. N. Engl. J. Med. 383, 1701-1703 (2020). doi:10.1056/NEJMp2027405 Medline

34. J. P. Moore, P. J. Klasse, SARS-CoV-2 vaccines: 'Warp Speed' needs mind melds not warped minds. J. Virol. 94, e01083-e20 (2020). doi:10.1128/JVI.01083-20 Medline

35. F. Krammer, SARS-CoV-2 vaccines in development. Nature 586, 516-527 (2020). doi:10.1038/s41586-020-2798-3 Medline

36. B. Korber, W. M. Fischer, S. Gnanakaran, H. Yoon, J. Theiler, W. Abfalterer, N. Hengartner, E. E. Giorgi, T. Bhattacharya, B. Foley, K. M. Hastie, M. D. Parker, D. G. Partridge, C. M. Evans, T. M. Freeman, T. I. de Silva, C. McDanal, L. G. Perez, H. Tang, A. Moon-Walker, S. P. Whelan, C. C. LaBranche, E. O. Saphire, D. C. Montefiori, A. Angyal, R. L. Brown, L. Carrilero, L. R. Green, D. C. Groves, K. J. Johnson, A. J. Keeley, B. B. Lindsey, P. J. Parsons, M. Raza, S. Rowland-Jones, N. Smith, R. M. Tucker, D. Wang, M. D. Wyles; Sheffield COVID-19 Genomics Group, Tracking changes in SARS-CoV-2 spike: Evidence that D614G increases infectivity of the COVID-19 virus. Cell 182, 812-827.e19 (2020) doi:10.1016/i.cell.2020.06.043 Medline

37. Y. J. Hou, S. Chiba, P. Halfmann, C. Ehre, M. Kuroda, K. H. Dinnon, S. R. Leist, A. Schäfer, N. Nakajima, K. Takahashi, R. E. Lee, T. M. Mascenik, C. E. Edwards, L. V. Tse, R. C. Boucher, S. H. Randell, T. Suzuki, L. E. Gralinski, Y. Kawaoka, R. S. Baric, SARS-CoV-2 D614G variant exhibits enhanced replication. bioRxiv 2020.09.28.317685 [Preprint] 29 Sep 2020; 10.1101/2020.09.28.317685

38. L. Yurkovetskiy, X. Wang, K. E. Pascal, C. Tomkins-Tinch, T. Nyalile, Y. Wang, A. Baum, W. E. Diehl, A. Dauphin, C. Carbone, K. Veinotte, S. B. Egri, S. F. Schaffner, J. E. Lemieux, J. Munro, A. Rafique, A. Barve, P. C. Sabeti, C. A. Kyratsous, N. Dudkina, K. Shen, J. Luban, SARS-CoV-2 Spike protein variant D614G increases infectivity and retains sensitivity to antibodies that target the receptor binding domain. bioRxiv 2020.07.04.187757 [Preprint] 16 July 2020;10.1101/2020.07.04.187757

39. C. L. Hsieh, J. A. Goldsmith, J. M. Schaub, A. M. DiVenere, H. C. Kuo, K. Javanmardi, K. C. Le, D. Wrapp, A. G. Lee, Y. Liu, C. W. Chou, P. O. Byrne, C. K. Hjorth, N. V. Johnson, J. Ludes-Meyers, A. W. Nguyen, J. Park, N. Wang, D. Amengor, J. J. Lavinder, G. C. Ippolito, J. A. Maynard, I. J. Finkelstein, J. S. McLellan, Structurebased design of prefusion-stabilized SARS-CoV-2 spikes. Science 369, 1501-1505 (2020). doi:10.1126/science.abd0826 Medline

40. J. S. McLellan, M. Chen, M. G. Joyce, M. Sastry, G. B. Stewart-Jones, Y. Yang, B. Zhang, L. Chen, S. Srivatsan, A. Zheng, T. Zhou, K. W. Graepel, A. Kumar, S. Moin, J. C. Boyington, G. Y. Chuang, C. Soto, U. Baxa, A. Q. Bakker, H. Spits, T. Beaumont, Z. Zheng, N. Xia, S. Y. Ko, J. P. Todd, S. Rao, B. S. Graham, P. D. Kwong, Structure-based design of a fusion glycoprotein vaccine for respiratory syncytial virus. Science 342, 592-598 (2013). doi:10.1126/science.1243283 Medline

41. J. Sadoff, E. De Paepe, W. Haazen, E. Omoruyi, A. R. Bastian, C. Comeaux, E. Heijnen, C. Strout, H. Schuitemaker, B. Callendret, Safety and immunogenicity of the Ad26.RSV.pref investigational vaccine coadministered with an Influenza vaccine in older adults. J. Infect. Dis. jiaa409 (2020). doi:10.1093/infdis/iiaa409 Medline

42. R. Bos, L. Rutten, J. E. M. van der Lubbe, M. J. G. Bakkers, G. Hardenberg, F. Wegmann, D. Zuijdgeest, A. H. de Wilde, A. Koornneef, A. Verwilligen, D. van Manen, T. Kwaks, R. Vogels, T. J. Dalebout, S. K. Myeni, M. Kikkert, E. J. Snijder, Z. 
Li, D. H. Barouch, J. Vellinga, J. P. M. Langedijk, R. C. Zahn, J. Custers, H. Schuitemaker, Ad26 vector-based COVID-19 vaccine encoding a prefusionstabilized SARS-CoV-2 Spike immunogen induces potent humoral and cellular immune responses. NPJ Vaccines 5, 91 (2020). doi:10.1038/s41541-020-00243$x$ Medline

43. F. Amanat, S. Strohmeier, R. Rathnasinghe, M. Schotsaert, L. Coughlan, A. GarcíaSastre, F. Krammer, Introduction of two prolines and removal of the polybasic cleavage site leads to optimal efficacy of a recombinant spike based SARS-CoV-2 vaccine in the mouse model. bioRxiv 2020.09.16.300970 [Preprint] 18 Sep 2020; $10.1101 / 2020.09 .16 .300970$

44. S. P. Buchbinder, M. J. McElrath, C. Dieffenbach, L. Corey, Use of adenovirus type5 vectored vaccines: A cautionary tale. Lancet 396, e68-e69 (2020). Medline

45. F. Amanat, F. Krammer, SARS-CoV-2 vaccines: Status report. Immunity 52, 583589 (2020). doi:10.1016/i.immuni.2020.03.007 Medline

46. T. R. F. Smith, A. Patel, S. Ramos, D. Elwood, X. Zhu, J. Yan, E. N. Gary, S. N. Walker, K. Schultheis, M. Purwar, Z. Xu, J. Walters, P. Bhojnagarwala, M. Yang, N. Chokkalingam, P. Pezzoli, E. Parzych, E. L. Reuschel, A. Doan, N. Tursi, M. Vasquez, J. Choi, E. Tello-Ruiz, I. Maricic, M. A. Bah, Y. Wu, D. Amante, D. H. Park, Y. Dia, A. R. Ali, F. I. Zaidi, A. Generotti, K. Y. Kim, T. A. Herring, S. Reeder, V. M. Andrade, K. Buttigieg, G. Zhao, J. M. Wu, D. Li, L. Bao, J. Liu, W. Deng, C. Qin, A. S. Brown, M. Khoshnejad, N. Wang, J. Chu, D. Wrapp, J. S. McLellan, K. Muthumani, B. Wang, M. W. Carroll, J. J. Kim, J. Boyer, D. W. Kulp, L. M. P. F. Humeau, D. B. Weiner, K. E. Broderick, Immunogenicity of a DNA vaccine candidate for COVID19. Nat. Commun. 11, 2601 (2020). doi:10.1038/s41467-020-16505-0 Medline

47. K. S. Corbett, D. K. Edwards, S. R. Leist, O. M. Abiona, S. Boyoglu-Barnum, R. A. Gillespie, S. Himansu, A. Schäfer, C. T. Ziwawo, A. T. DiPiazza, K. H. Dinnon, S. M. Elbashir, C. A. Shaw, A. Woods, E. J. Fritch, D. R. Martinez, K. W. Bock, M. Minai, B. M. Nagata, G. B. Hutchinson, K. Wu, C. Henry, K. Bahl, D. Garcia-Dominguez, L. Ma, I. Renzi, W. P. Kong, S. D. Schmidt, L. Wang, Y. Zhang, E. Phung, L. A. Chang, R. J. Loomis, N. E. Altaras, E. Narayanan, M. Metkar, V. Presnyak, C. Liu, M. K. Louder, W. Shi, K. Leung, E. S. Yang, A. West, K. L. Gully, L. J. Stevens, N. Wang, D. Wrapp, N. A. Doria-Rose, G. Stewart-Jones, H. Bennett, G. S. Alvarado, M. C. Nason, T. J. Ruckwardt, J. S. McLellan, M. R. Denison, J. D. Chappell, I. N. Moore, K. M. Morabito, J. R. Mascola, R. S. Baric, A. Carfi, B. S. Graham, SARS-CoV-2 mRNA vaccine design enabled by prototype pathogen preparedness. Nature 586 , 567-571 (2020). doi:10.1038/s41586-020-2622-0 Medline

48. S. P. Graham, R. K. McLean, A. J. Spencer, S. Belij-Rammerstorfer, D. Wright, M. Ulaszewska, J. C. Edwards, J. W. P. Hayes, V. Martini, N. Thakur, C. Conceicao, I. Dietrich, H. Shelton, R. Waters, A. Ludi, G. Wilsden, C. Browning, D. Bialy, S. Bhat, P. Stevenson-Leggett, P. Hollinghurst, C. Gilbride, D. Pulido, K. Moffat, H. Sharpe, E. Allen, V. Mioulet, C. Chiu, J. Newman, A. S. Asfor, S. Burman, S. Crossley, J. Huo, R. J. Owens, M. Carroll, J. A. Hammond, E. Tchilian, D. Bailey, B. Charleston, S. C. Gilbert, T. J. Tuthill, T. Lambe, Evaluation of the immunogenicity of prime-boost vaccination with the replication-deficient viral vectored COVID-19 vaccine candidate ChAdOx1 nCoV-19. NPJ Vaccines 5, 69 (2020). doi:10.1038/s41541020-00221-3

49. L. H. Tostanoski, F. Wegmann, A. J. Martinot, C. Loos, K. McMahan, N. B. Mercado, J. Yu, C. N. Chan, S. Bondoc, C. E. Starke, M. Nekorchuk, K. Busman-Sahay, C. Piedra-Mora, L. M. Wrijil, S. Ducat, J. Custers, C. Atyeo, S. Fischinger, J. S. Burke, J. Feldman, B. M. Hauser, T. M. Caradonna, E. A. Bondzie, G. Dagotto, M. S. Gebre, C. Jacob-Dolan, Z. Lin, S. H. Mahrokhian, F. Nampanya, R. Nityanandam, L. Pessaint, M. Porto, V. Ali, D. Benetiene, K. Tevi, H. Andersen, M. G. Lewis, A. G. Schmidt, D. A. Lauffenburger, G. Alter, J. D. Estes, H. Schuitemaker, R. Zahn, D. H. Barouch, Ad26 vaccine protects against SARS-CoV-2 severe clinical disease in hamsters. Nat. Med. 26, 1694-1700 (2020). 10.1101/2020.09.27.20189548 Medline

50. A. O. Hassan, N. M. Kafai, I. P. Dmitriev, J. M. Fox, B. K. Smith, I. B. Harvey, R. E. Chen, E. S. Winkler, A. W. Wessel, J. B. Case, E. Kashentseva, B. T. McCune, A. L. Bailey, H. Zhao, L. A. VanBlargan, Y. N. Dai, M. Ma, L. J. Adams, S. Shrihari, J. E. Danis, L. E. Gralinski, Y. J. Hou, A. Schäfer, A. S. Kim, S. P. Keeler, D. Weiskopf, R. S. Baric, M. J. Holtzman, D. H. Fremont, D. T. Curiel, M. S. Diamond, A single-dose intranasal ChAd vaccine protects upper and lower respiratory tracts against SARS-CoV-2. Cell 183, 169-184.e13 (2020). doi:10.1016/i.cell.2020.08.026 Medline

51. D. S. Khoury, A. K. Wheatley, M. D. Ramuta, A. Reynaldi, D. Cromer, K. Subbarao,
D. H. O'Connor, S. J. Kent, M. P. Davenport, Measuring immunity to SARS-CoV-2 infection: Comparing assays and animal models. Nat. Rev. Immunol. 20, 727-738 (2020). doi:10.1038/s41577-020-00471-1 Medline

52. P. J. Klasse, Neutralization of virus infectivity by antibodies: Old problems in new perspectives. Adv. Biol. 2014, 157895 (2014). 10.1155/2014/157895 Medline

53. J. Seow, C. Graham, B. Merrick, S. Acors, S. Pickering, K. J. A. Steel, O. Hemmings, A. O'Byrne, N. Kouphou, R. P. Galao, G. Betancor, H. D. Wilson, A. W. Signell, H. Winstone, C. Kerridge, I. Huettner, J. M. Jimenez-Guardeño, M. J. Lista, N. Temperton, L. B. Snell, K. Bisnauthsing, A. Moore, A. Green, L. Martinez, B. Stokes, J. Honey, A. Izquierdo-Barras, G. Arbane, A. Patel, M. K. I. Tan, L. O'Connell, G. O'Hara, E. MacMahon, S. Douthwaite, G. Nebbia, R. Batra, R. Martinez-Nunez, M. Shankar-Hari, J. D. Edgeworth, S. J. D. Neil, M. H. Malim, K. J. Doores, Longitudinal observation and decline of neutralizing antibody responses in the three months following SARS-CoV-2 infection in humans. Nat. Microbiol. 5, 1598-1607 (2020). doi:10.1038/s41564-020-00813-8 Medline

54. C. Gaebler, Z. Wang, J. C. C. Lorenzi, F. Muecksch, S. Finkin, M. Tokuyama, M. Ladinsky, A. Cho, M. Jankovic, D. Schaefer-Babajew, T. Y. Oliveira, M. Cipolla, C. Viant, C. O. Barnes, A. Hurley, M. Turroja, K. Gordon, K. G. Millard, V. Ramos, F. Schmidt, Y. Weisblum, D. Jha, M. Tankelevich, J. Yee, I. Shimeliovich, D. F. Robbiani, Z. Zhao, A. Gazumyan, T. Hatziioannou, P. J. Bjorkman, S. Mehandru, P. D. Bieniasz, M. Caskey, M. C. Nussenzweig, Evolution of antibody immunity to SARS-CoV-2. bioRxiv 2020.11.03.367391 [Preprint] 05 Nov 2020; 10.1101/2020.11.03.367391

55. J. M. Dan, J. Mateus, Y. Kato, K. M. Hastie, C. E. Faliti, S. I. Ramirez, A. Frazier, E. D. Yu, A. Grifoni, S. A. Rawlings, B. Peters, F. Krammer, V. Simon, E. O. Saphire, D. M. Smith, D. Weiskopf, A. Sette, S. Crotty, Immunological memory to SARS-CoV-2 assessed for greater than six months after infection. bioRxiv 2020.11.15.383323 [Preprint] 16 Nov 2020; 10.1101/2020.11.15.383323

56. R. R. Regoes, C. Magnus, The role of chance in primate lentiviral infectivity: From protomer to host organism. Prog. Mol. Biol. Transl. Sci. 129, 327-351 (2015). doi:10.1016/bs.pmbts.2014.10.013 Medline

57. G. Makedonas, M. R. Betts, Living in a house of cards: Re-evaluating CD8+ T-cell immune correlates against HIV. Immunol. Rev. 239, 109-124 (2011). doi:10.1111/j.1600-065X.2010.00968.x Medline

58. D. R. Burton, L. M. Walker, Rational vaccine design in the time of COVID-19. Cell Host Microbe 27, 695-698 (2020). doi:10.1016/j.chom.2020.04.022 Medline

59. B. S. Graham, G. S. Henderson, Y. W. Tang, X. Lu, K. M. Neuzil, D. G. Colley, Priming immunization determines $T$ helper cytokine mRNA expression patterns in lungs of mice challenged with respiratory syncytial virus. J. Immunol. 151, 2032-2040 (1993). Medline

60. B. S. Graham, Rapid COVID-19 vaccine development. Science 368, 945-946 (2020). doi:10.1126/science.abb8923 Medline

61. J. Cote-Sierra, G. Foucras, L. Guo, L. Chiodetti, H. A. Young, J. Hu-Li, J. Zhu, W. E. Paul, Interleukin 2 plays a central role in Th2 differentiation. Proc. Natl. Acad. Sci. U.S.A. 101, 3880-3885 (2004). doi:10.1073/pnas.04003339101 Medline

62. S. Wu, G. Zhong, J. Zhang, L. Shuai, Z. Zhang, Z. Wen, B. Wang, Z. Zhao, X. Song Y. Chen, R. Liu, L. Fu, J. Zhang, Q. Guo, C. Wang, Y. Yang, T. Fang, P. Lv, J. Wang, J. Xu, J. Li, C. Yu, L. Hou, Z. Bu, W. Chen, A single dose of an adenovirus-vectored vaccine provides protection against SARS-CoV-2 challenge. Nat. Commun. 11 , 4081 (2020). Medline

63. S. Bangaru, G. Ozorowski, H. L. Turner, A. Antanasijevic, D. Huang, X. Wang, J. L. Torres, J. K. Diedrich, J. H. Tian, A. D. Portnoff, N. Patel, M. J. Massare, J. R. Yates 3rd, D. Nemazee, J. C. Paulson, G. Glenn, G. Smith, A. B. Ward, Structural analysis of full-length SARS-CoV-2 spike protein from an advanced vaccine candidate. Science 370, 1089-1094 (2020). doi:10.1126/science.abe1502 Medline

64. S. J. Cleary, S. C. Pitchford, R. T. Amison, R. Carrington, C. L. Robaina Cabrera, M. Magnen, M. R. Looney, E. Gray, C. P. Page, Animal models of mechanisms of SARS-CoV-2 infection and COVID-19 pathology. Br. J. Pharmacol. 177, 4851-4865 (2020). doi:10.1111/bph.15143 Medline

65. V. J. Munster, F. Feldmann, B. N. Williamson, N. van Doremalen, L. Pérez-Pérez, J. Schulz, K. Meade-White, A. Okumura, J. Callison, B. Brumbaugh, V. A. Avanzato, R. Rosenke, P. W. Hanley, G. Saturday, D. Scott, E. R. Fischer, E. de Wit, Respiratory disease in rhesus macaques inoculated with SARS-CoV-2. Nature 585, 268-272 (2020). doi:10.1038/s41586-020-2324-7 Medline

66. B. Rockx, T. Kuiken, S. Herfst, T. Bestebroer, M. M. Lamers, B. B. Oude Munnink, 
D. de Meulder, G. van Amerongen, J. van den Brand, N. M. A. Okba, D. Schipper, P. van Run, L. Leijten, R. Sikkema, E. Verschoor, B. Verstrepen, W. Bogers, J. Langermans, C. Drosten, M. Fentener van Vlissingen, R. Fouchier, R. de Swart, M. Koopmans, B. L. Haagmans, Comparative pathogenesis of COVID-19, MERS, and SARS in a nonhuman primate model. Science 368, 1012-1015 (2020). doi:10.1126/science. abb7314 Medline

67. R. Wölfel, V. M. Corman, W. Guggemos, M. Seilmaier, S. Zange, M. A. Müller, D. Niemeyer, T. C. Jones, P. Vollmar, C. Rothe, M. Hoelscher, T. Bleicker, S. Brünink, J. Schneider, R. Ehmann, K. Zwirglmaier, C. Drosten, C. Wendtner, Virological assessment of hospitalized patients with COVID-2019. Nature 581, 465-469 (2020). doi:10.1038/s41586-020-2196-x Medline

68. P. J. Klasse, G. Ozorowski, R. W. Sanders, J. P. Moore, Env exceptionalism: Why are HIV-1 Env glycoproteins atypical immunogens? Cell Host Microbe 27, 507-518 (2020). doi:10.1016/i.chom.2020.03.018 Medline

69. S. A. Plotkin, Correlates of protection induced by vaccination. Clin. Vaccine Immunol. 17, 1055-1065 (2010). doi:10.1128/CVI.00131-10 Medline

70. P. J. Klasse, J. P. Moore, Good CoP, bad CoP? Interrogating the immune responses to primate lentiviral vaccines. Retrovirology 9, 80 (2012). doi:10.1186/1742-46909-80 Medline

71. A. Addetia, K. H. D. Crawford, A. Dingens, H. Zhu, P. Roychoudhury, M. L. Huang, K. R. Jerome, J. D. Bloom, A. L. Greninger, Neutralizing antibodies correlate with protection from SARS-CoV-2 in humans during a fishery vessel outbreak with high attack rate. J. Clin. Microbiol. 58, e02107-e02120 (2020). doi:10.1128/JCM.02107-20 Medline

72. F. Schmidt, Y. Weisblum, F. Muecksch, H. H. Hoffmann, E. Michailidis, J. C. C. Lorenzi, P. Mendoza, M. Rutkowska, E. Bednarski, C. Gaebler, M. Agudelo, A. Cho, Z. Wang, A. Gazumyan, M. Cipolla, M. Caskey, D. F. Robbiani, M. C. Nussenzweig, C. M. Rice, T. Hatziioannou, P. D. Bieniasz, Measuring SARS-CoV-2 neutralizing antibody activity using pseudotyped and chimeric viruses. J. Exp. Med. 217, e20201181 (2020). doi:10.1084/iem.20201181 Medline

73. K.Y. Oguntuyo, C.S. Stevens, C.T. Hung, S. Ikegame, J.A. Acklin, S.S. Kowdle, J.C. Carmichael, H.P. Chiu, K.D. Azarm, G.D. Haas, F. Amanat, J. Klingler, I. Baine, S. Arinsburg, J.C. Bandres, M.N. Siddiquey, R.M. Schilke, M.D. Woolard, H. Zhang, A.J. Duty, T.A. Kraus, T.M. Moran, D. Tortorella, J.K. Lim, A.V. Gamarnik, C.E. Hioe, S. Zolla-Pazner, S.S. Ivanov, J.P. Kamil, F. Krammer, B. Lee, Quantifying absolute neutralization titers against SARS-CoV-2 by a standardized virus neutralization assay allows for cross-cohort comparisons of COVID-19 sera. medRxiv.10.1101/2020.08.13.20157222. (2020).

74. F. P. Polack, S. J. Thomas, N. Kitchin, J. Absalon, A. Gurtman, S. Lockhart, J. L. Perez, G. Pérez Marc, E. D. Moreira, C. Zerbini, R. Bailey, K. A. Swanson, S. Roychoudhury, K. Koury, P. Li, W. V. Kalina, D. Cooper, R. W. Frenck Jr., L. L. Hammitt, Ö. Türeci, H. Nell, A. Schaefer, S. Ünal, D. B. Tresnan, S. Mather, P. R. Dormitzer, U. Şahin, K. U. Jansen, W. C. Gruber, for the C4591001 Clinical Trial Group, Safety and efficacy of the BNT162b2 mRNA COVID-19 vaccine. N. Engl. J. Med. 383, 2603-2615 (2020). doi:10.1056/NEJMoa2034577 Medline

75. T. Widge, N. G. Rouphael, L. A. Jackson, E. J. Anderson, P. C. Roberts, M. Makhene, J. D. Chappell, M. R. Denison, L. J. Stevens, A. J. Pruijssers, A. B. McDermott, B. Flach, B. C. Lin, N. A. Doria-Rose, S. O'Dell, S. D. Schmidt, K. M. Neuzil, H. Bennett, B. Leav, M. Makowski, J. Albert, K. Cross, V. V. Edara, K. Floyd, M. S. Suthar, W. Buchanan, C. J. Luke, J. E. Ledgerwood, J. R. Mascola, B. S. Graham, J. H. Beigel, for the m.-S. Group, Durability of responses after SARS-CoV2 mRNA-1273 vaccination. N. Engl. J. Med. (2020).

76. J. R. Barrett, S. Belij-Rammerstorfer, C. Dold, K. J. Ewer, P. M. Folegatti, C. Gilbride, R. Halkerston, J. Hill, D. Jenkin, L. Stockdale, M. K. Verheul, P. K. Aley, B. Angus, D. Bellamy, E. Berrie, S. Bibi, M. Bittaye, M. W. Carroll, B. Cavell, E. A. Clutterbuck, N. Edwards, A. Flaxman, M. Fuskova, A. Gorringe, B. Hallis, S. Kerridge, A. M. Lawrie, A. Linder, X. Liu, M. Madhavan, R. Makinson, J. Mellors, A. Minassian, M. Moore, Y. Mujadidi, E. Plested, I. Poulton, M. N. Ramasamy, H. Robinson, C. S. Rollier, R. Song, M. D. Snape, R. Tarrant, S. Taylor, K. M. Thomas, M. Voysey, M. E. E. Watson, D. Wright, A. D. Douglas, C. M. Green, A. V. S. Hill, T. Lambe, S. Gilbert, A. J. Pollard, O. C. V. T. Group, Phase 1/2 trial of SARS-CoV-2 vaccine ChAdOx1 $\mathrm{nCoV}-19$ with a booster dose induces multifunctional antibody responses. Nat. Med. (2020). Medline

77. M. Voysey, S. A. C. Clemens, S. A. Madhi, L. Y. Weckx, P. M. Folegatti, P. K. Aley, B. Angus, V. L. Baillie, S. L. Barnabas, Q. E. Bhorat, S. Bibi, C. Briner, P. Cicconi, A. M.
Collins, R. Colin-Jones, C. L. Cutland, T. C. Darton, K. Dheda, C. J. A. Duncan, K. R. W. Emary, K. J. Ewer, L. Fairlie, S. N. Faust, S. Feng, D. M. Ferreira, A. Finn, A. L. Goodman, C. M. Green, C. A. Green, P. T. Heath, C. Hill, H. Hill, I. Hirsch, S. H. C. Hodgson, A. Izu, S. Jackson, D. Jenkin, C. C. D. Joe, S. Kerridge, A. Koen, G. Kwatra, R. Lazarus, A. M. Lawrie, A. Lelliott, V. Libri, P. J. Lillie, R. Mallory, A. V. A. Mendes, E. P. Milan, A. M. Minassian, A. McGregor, H. Morrison, Y. F. Mujadidi, A. Nana, P. J. O'Reilly, S. D. Padayachee, A. Pittella, E. Plested, K. M. Pollock, M. N. Ramasamy, S. Rhead, A. V. Schwarzbold, N. Singh, A. Smith, R. Song, M. D. Snape, E. Sprinz, R. K. Sutherland, R. Tarrant, E. C. Thomson, M. E. Török, M. Toshner, D. P. J. Turner, J. Vekemans, T. L. Villafana, M. E. E. Watson, C. J. Williams, A. D. Douglas, A. V. S. Hill, T. Lambe, S. C. Gilbert, A. J. Pollard, O. C. V. T. Group, Safety and efficacy of the ChAdOx1 nCoV-19 vaccine (AZD1222) against SARS-CoV-2: An interim analysis of four randomized controlled trials in Brazil, South Africa, and the UK. Lancet (2020). Medline

78. E. Gabitzsch, J. T. Safrit, M. Verma, A. Rice, P. Sieling, L. Zakin, A. Shin, B. Morimoto, H. Adisetiyo, R. Wong, A. Bezawada, K. Dinkins, J. Balint, V. Peykov, H. Garban, P. Liu, A. Bacon, J. Drew, P. Spilman, L. Sender, S. Rabizadeh, K. Niazi, P. Soon-Shiong, Complete Protection of Nasal and Lung Airways Against SARS-CoV2 Challenge by Antibody Plus Th1 Dominant N- and S-Specific T-Cell Responses to Subcutaneous Prime and Thermally-Stable Oral Boost Bivalent hAd5 Vaccination in an NHP Study. bioRxiv 2020.12.08.416297 [Preprint] 09 Dec 2020; 10.1101/2020.12.08.416297

79. X. Y. Zhang, J. Guo, X. Wan, J. G. Zhou, W. P. Jin, J. Lu, W. H. Wang, A. N. Yang, D. X. Liu, Z. L. Shi, Z. M. Yuan, X. G. Li, S. L. Meng, K. Duan, Z. J. Wang, X. M. Yang, S. Shen, Biochemical and antigenic characterization of the structural proteins and their post-translational modifications in purified SARS-CoV-2 virions of an inactivated vaccine candidate. Emerg. Microbes Infect. 9, 2653-2662 (2020). doi:10.1080/22221751.2020.1855945 Medline

80. Z. J. Wang, H. J. Zhang, J. Lu, K. W. Xu, C. Peng, J. Guo, X. X. Gao, X. Wan, W. H. Wang, C. Shan, S. C. Zhang, J. Wu, A. N. Yang, Y. Zhu, A. Xiao, L. Zhang, L. Fu, H. R. Si, Q. Cai, X. L. Yang, L. You, Y. P. Zhou, J. Liu, D. Q. Pang, W. P. Jin, X. Y. Zhang, S. L. Meng, Y. X. Sun, U. Desselberger, J. Z. Wang, X. G. Li, K. Duan, C. G. Li, M. Xu, Z. L. Shi, Z. M. Yuan, X. M. Yang, S. Shen, Low toxicity and high immunogenicity of an inactivated vaccine candidate against COVID-19 in different animal models. Emerg. Microbes Infect. 9, 2606-2618 (2020). doi:10.1080/22221751.2020.1852059 Medline

81. R. Ella, K. M. Vadrevu, H. Jogdand, S. Prasad, S. Reddy, V. Sarangi, B. Ganneru, G. Sapkal, P. Yadav, P. Abraham, S. Panda, N. Gupta, P. Reddy, S. Verma, S. K. Rai, C. Singh, S. V. Redkar, C. S. Gillurkar, J. S. Kushwaha, S. Mohapatra, V. Rao, R. Guleria, K. Ella, B. Bhargava, A Phase 1: Safety and Immunogenicity Trial of an Inactivated SARS-CoV-2 Vaccine-BBV152. medRxiv 2020.12.11.20210419 [Preprint] 15 Dec 2020; 10.1101/2020.12.11.20210419

82. R. Ella, S. Reddy, H. Jogdand, V. Sarangi, B. Ganneru, S. Prasad, D. Das, D. Raju, U. Praturi, G. Sapkal, P. Yadav, P. Reddy, S. Verma, C. Singh, S. V. Redkar, C. S. Gillurkar, J. S. Kushwaha, S. Mohapatra, A. Bhate, S. Rai, S. Panda, P. Abraham, N. Gupta, K. Ella, B. Bhargava, K. M. Vadrevu, Safety and immunogenicity clinical trial of an inactivated SARS-CoV-2 vaccine, BBV152 (a phase 2, double-blind, randomised controlled trial) and the persistence of immune responses from a phase 1 follow-up report. medRxiv 2020.12.21.20248643 [Preprint] 22 Dec 2020; 10.1101/2020.12.21.20248643

83. S. Yang, Y. Li, L. Dai, J. Wang, P. He, C. Li, X. Fang, C. Wang, X. Zhao, E. Huang, C. Wu, Z. Zhong, F. Wang, X. Duan, S. Tian, L. Wu, Y. Liu, Y. Luo, Z. Chen, F. Li, J. Li, X. Yu, H. Ren, L. Liu, S. Meng, J. Yan, Z. Hu, L. Gao, G. F. Gao, Safety and immunogenicity of a recombinant tandem-repeat dimeric RBD protein vaccine against COVID-19 in adults: pooled analysis of two randomized, double-blind, placebo-controlled, phase 1 and 2 trials medRxiv 2020.12.20.20248602 [Preprint] 22 Dec 2020; 10.1101/2020.12.20.20248602

\section{ACKNOWLEDGMENTS}

We are grateful to Kathrina Guemo for administrative support, and to Natalie Dean for helpful comments on the press releases summarized here. Funding: This work was supported by the National Institute of Allergy and Infectious Diseases of the NIH (HIVRAD P01 Al110657 and R01 Al36082) and the Bill and Melinda Gates Foundation (OPP1132237 and INV-002022). Competing interests: The authors declare no competing interests. Data and materials availability: All data 
needed to evaluate the conclusions in the paper are present in the paper or referenced materials.

\section{SUPPLEMENTARY MATERIALS}

advances.sciencemag.org/cgi/content/full/sciadv.abe8065/DC1

Submitted 15 September 2020

Accepted 22 January 2021

Published First Release 19 February 2021

10.1126/sciadv.abe8065 
Table 1: SARS-CoV-2 vaccines under evaluation in NHPs and Phase 1/2 human trials

\begin{tabular}{|c|c|c|c|c|}
\hline Vaccine name $^{a}$ & Sponsorb & Design principle $^{c}$ & $\begin{array}{l}\text { NHP studies } \\
\text { (citation) }\end{array}$ & $\begin{array}{l}\text { Human trials } \\
\text { (citation) }\end{array}$ \\
\hline PiCoVacc/CoronaVac ${ }^{d}$ & Sinovac & Inactivated virus & $(1)$ & $(14)$ \\
\hline BBIBP-CorV & Sinopharm/BIBP & Inactivated virus & (2) & $(14)$ \\
\hline $\begin{array}{l}\text { ChAdOx1 nCoV-19 } \\
\text { (AZD1222) }\end{array}$ & AstraZeneca & ChAdeno virus-S-protein & (3) & $(16,17)$ \\
\hline Ad26.COV2 & Janssen & Ad26 virus-S-protein & $(4,5)$ & $(18)$ \\
\hline Various constructs & Not applicable e & DNA-S-protein & $(6)$ & \\
\hline INO-4800 & Inovio & DNA-S-protein & (7) & \\
\hline mRNA-1273 & Moderna & mRNA-S-protein & (8) & $(19,20)$ \\
\hline NVX-CoV2373 & Novavax & Recombinant S-protein & $(9,10)$ & $(21)$ \\
\hline Unnamed & Sinopharm/WIBP & Inactivated virus & & $(22)$ \\
\hline Ad5-nCoV & CanSinoBIO & Ad5 virus-S-protein & & $(23,24)$ \\
\hline BNT162b1 ${ }^{\dagger}$ & Pfizer/BioNTech & mRNA-RBD & (11) & $(25-27)$ \\
\hline BNT162b2 & & mRNA-S-protein & & \\
\hline $\begin{array}{l}\text { Gam-COVID-Vac } \\
\text { (Sputnik V) }\end{array}$ & Gamaleya Center & Ad26 + Ad5 virus-S-protein & & $(28)$ \\
\hline S-Trimer & Clover Biopharm. & Recombinant S-protein & $(12)$ & \\
\hline KMS-1 & IMB, CAMS, PUMC & Inactivated virus & & $(29,30)$ \\
\hline MRT5500 & Sanofi Pasteur & mRNA-S-protein & (13) & \\
\hline CoVLP & Medicago & S-protein virus-like particles & & $(31)$ \\
\hline CVnCoV & Curevac & mRNA-S-protein & & (32) \\
\hline
\end{tabular}

Some vaccines have alternative names or corporate designations. We use the same names as in the papers cited. The entries in this column are arranged in approximate order of appearance of the first relevant paper on a preprint server or journal website. The citations are arranged such that the papers on the NHP studies are all numbered before those on human trials.

${ }^{b}$ The five companies highlighted in bold in this and subsequent tables are part of the US Government's Operation Warp Speed program or, in the case of Pfizer/BioNTech, have close ties to it. As this program rapidly evolves, readers should consult appropriate websites (e.g., https://medicalcountermeasures.gov/app/barda/coronavirus/COVID19.aspx) for updated information. In some cases, the companies have academic partners. For example, Moderna is the corporate partner of the NIH's Vaccine Research Center, where the mRNA construct was designed, while the AstraZeneca vaccine (also known as AZD1222) similarly involves the Oxford University in the UK, and Medicago's CoVLP vaccine program is a collaboration with McGill University in Canada. BIBP = Beijing Institute of Biological Products; WIBP = Wuhan Institute of Biological Products. Both these organizations are part of the Sinopharm consortium. The Gamaleya Center in Moscow has multiple partners within the Ministry of Health of the Russian Federation. IMB, CAMS, PUMC = Institute of Medical Biology, Chinese Academy of Medical Sciences, Peking Union Medical College.

c The SARS-CoV-2 components of these vaccines are all based on the S-protein or, in the case of the Pfizer/BioNTech now abandoned BNT162b1, the S-protein's RBD. The Adenovirus, mRNA and DNA vaccines express the full-length Sprotein. Truncated variants have been studied as comparator immunogens $(4,6)$. The recombinant protein vaccines are based on stabilized S-full-length S proteins. The inactivated virus vaccines all include S-proteins together with other viral components. For full details of the immunogens, including modifications made to the S-proteins, the primary papers should be consulted.

d The Sinovac vaccine was named PiCoVacc at the preclinical stage and then renamed CoronaVac when it moved into human trials.

e The DNA vaccines tested in the macaque study are not known to be part of a clinical development program; we include this paper in the review because it has a macaque challenge component and is therefore relevant to the comparison with other such studies.

${ }^{\mathrm{f}}$ Although both vaccines were studied at Phase 1, only BNT162b2 was advanced into Phase 2/3. 
Table 2. Vaccine immunogenicity in NHP studies

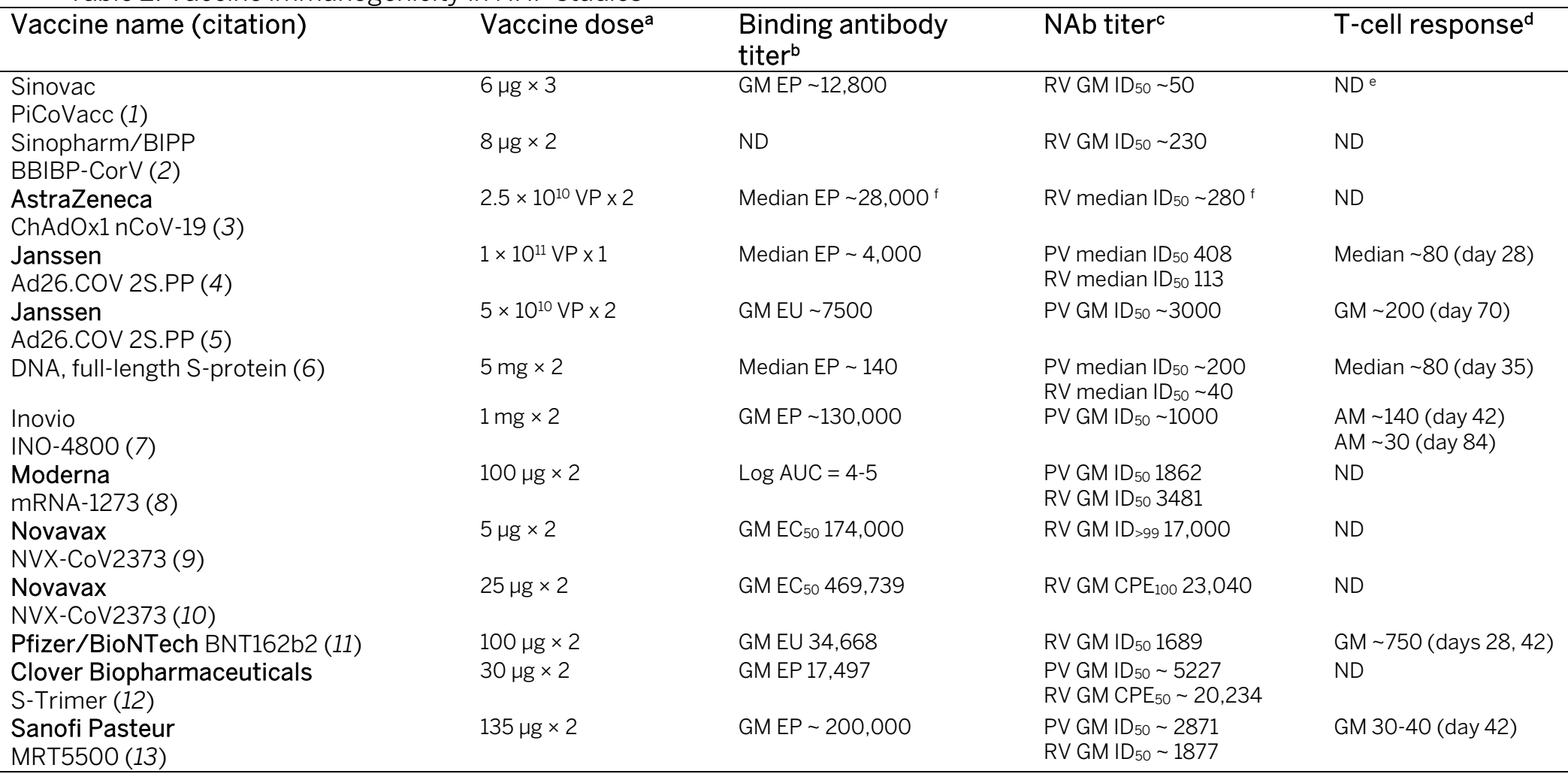

a Only results for the optimal dose, i.e., the strongest responses without unacceptable side effects, are recorded. When the number of immunizations differed between groups, the one inducing the strongest response was chosen. VP= virus particle.

${ }^{b}$ Antibody binding was measured in S-protein IgG ELISA 2 weeks after the last immunization and the values are listed as $E_{50}$, endpoint (EP) or ELISA units derived from comparison with a standard curve (EU); $G M=$ geometric mean; $A \cup C=$ area under the curve.

${ }^{c}$ Neutralization was quantified in PV or RV assays, as indicated. The potency was measured as ID 50 or ID>99 values (CPE 100 in ref. 10 is the approximate equivalent of $I D_{>99}$ in ref. 9).

d T-cell responses measured in ELISPOT IFN-gamma assays SFC $/ 10^{6}$ cells after stimulation with different SARS-CoV-2 S-derived peptides. The days between immunization (day 0 ) and sampling are also listed (in brackets). $A M=$ arithmetic mean.

e ND = not done (no data were presented in the paper).

${ }^{f}$ Data are for the 2 dose (prime boost) group. 
Table 3. Antibody responses at the time of challenge and degree of protection in NHP studies

\begin{tabular}{|c|c|c|c|c|}
\hline Vaccine name (citation) & $\begin{array}{c}\text { Binding antibody titer } \\
\text { near time of chal- } \\
\text { lenge }\end{array}$ & $\begin{array}{l}\text { NAb titer near time of } \\
\text { challenge }^{b}\end{array}$ & $\begin{array}{l}\text { Dose and route of chal- } \\
\text { lenge }^{c}\end{array}$ & $\begin{array}{c}\text { Time from last } \\
\text { immunization to } \\
\text { challenge }\end{array}$ \\
\hline $\begin{array}{l}\text { Sinovacc } \\
\text { PiCoVacc (1) }\end{array}$ & $\begin{array}{c}\text { GM EP } \sim 12,800 \\
1 \text { day } B C\end{array}$ & $\begin{array}{c}\text { RV GM ID } D_{50} \sim 50 \\
1 \text { day BC }\end{array}$ & $1 \times 10^{6} \mathrm{TCID}_{50} \mathrm{IT}$ & 22 days \\
\hline $\begin{array}{l}\text { Sinopharm/BIBP } \\
\text { BBIBP-CorV (2) }\end{array}$ & $N D^{e}$ & $\begin{array}{l}\mathrm{RV} \text { GM ID } \mathrm{D}_{50}-230 \\
\text { Day of challenge }\end{array}$ & $1 \times 10^{6} \mathrm{TCID}_{50} \mathrm{IT}$ & 14 days \\
\hline $\begin{array}{l}\text { AstraZeneca } \\
\text { ChAdOx1 nCoV-19 (3) }\end{array}$ & $\begin{array}{l}\text { Median EP } \sim 6300^{\mathrm{g}} \\
28 \text { days BC }\end{array}$ & $\begin{array}{l}\mathrm{RV} \text { median } \mathrm{ID}_{50} \sim 60 \\
28 \text { days } \mathrm{BC}\end{array}$ & $\begin{array}{c}(1.6+0.8+0.8+0.2) \times 10^{6} \\
\text { TCID } \text { IT IT IN-OR-OC }^{h}\end{array}$ & 14 days \\
\hline $\begin{array}{l}\text { Janssen } \\
\text { Ad26.COV 2S.PP (4) }\end{array}$ & $\begin{array}{l}\text { Median EP } \sim 4000 \\
14 \text { days BC }\end{array}$ & $\begin{array}{l}\text { PV median ID }{ }_{50} 408 \\
\text { RV median ID } D_{50} 113 \\
14 \text { days BC }\end{array}$ & $1 \times 10^{5} \mathrm{TCID}_{50} \mathrm{IT}-\mathrm{IN}$ & 42 days \\
\hline Full-length S-protein (6) & $\begin{array}{l}\text { Median EP } \sim 160 \\
\quad 7 \text { days BC }\end{array}$ & $\begin{array}{c}\text { PV median ID } \mathrm{D}_{50} \sim 40 \\
\text { RV median ID } \mathrm{D}_{50} \sim 200 \\
7 \text { days BC }\end{array}$ & $\begin{array}{c}1.2 \times 10^{8} \mathrm{VP}=1.1 \times 10^{4} \mathrm{PFU} \\
\mathrm{IT}-\mathrm{IN}\end{array}$ & 21 days \\
\hline $\begin{array}{l}\text { Inovio } \\
\text { INO-4800 (7) }\end{array}$ & $\begin{array}{c}\text { GM EP } \sim 3200 \\
14 \text { days BC }\end{array}$ & $\begin{array}{c}\text { PV GM ID } 50 \sim 260 \\
14 \text { days BC }\end{array}$ & $1.1 \times 10^{4}$ PFU IT-IN & 77 days \\
\hline $\begin{array}{l}\text { Moderna } \\
\text { mRNA-1273 (8) }\end{array}$ & $\begin{array}{l}\text { Log } A \cup C=4-5 \\
14 \text { days BC }\end{array}$ & $\begin{array}{c}\text { PV GM ID } D_{50} 1862 \\
\text { RV GM ID } D_{50} 3481 \\
14 \text { days BC }\end{array}$ & $\begin{array}{c}7.6 \times 10^{5} \mathrm{PFU} \\
1 \times 10^{6} \mathrm{TCID}_{50} \mathrm{IT}-\mathrm{IN}\end{array}$ & 28 days \\
\hline $\begin{array}{l}\text { Novavax } \\
\text { NVX-CoV2373 (10) }\end{array}$ & $\begin{array}{l}\mathrm{GM} \mathrm{EC}_{50} 469,739 \\
\text { Day of challenge }\end{array}$ & $\begin{array}{l}\mathrm{RV} \mathrm{GM} \mathrm{CPE} \mathrm{E}_{100} 23,040 \\
\text { Day of challenge }\end{array}$ & $1.04 \times 10^{4}$ PFU IT - IN & 35 days \\
\hline $\begin{array}{l}\text { Pfizer/BioNTech } \\
\text { BNT162b2 (11) }\end{array}$ & $\begin{array}{l}\text { GM EU } 6317 \\
20 \text { days BC }\end{array}$ & $\begin{array}{l}R V \text { GM ID } 50310 \\
20 \text { days BC }\end{array}$ & $1.05 \times 10^{6}$ PFU IT-IN & 55 days \\
\hline $\begin{array}{l}\text { Clover Biopharm. } \\
\text { S-Trimer (12) }\end{array}$ & $\begin{array}{l}\text { GM EP 17,497 } \\
\text { Day of challenge }\end{array}$ & $\begin{array}{c}\text { PV GM ID } D_{50} \sim 5227 \\
\text { RV GM CPE } 50 \sim 20,234 \\
\text { Day of challenge }\end{array}$ & $\begin{array}{l}2.6 \times 10^{6} \mathrm{TCID} 50 \\
\text { IT }(60 \%) \text { IN (40\%) }\end{array}$ & 14 days \\
\hline
\end{tabular}

${ }^{a}$ Antibody binding was measured in S-protein IgG ELISA and the values are listed as $\mathrm{EC}_{50}$, endpoint (EP) or ELISA units derived from comparison with a standard curve (EU); GM = geometric mean; $A U C=$ area under the curve. The data are derived from the timepoint (listed in days) closest to the time of challenge. BC = before challenge

${ }^{b}$ Neutralization was quantified in PV or RV assays, as indicated and the potency measured as ID $D_{50}$ or $C P E_{100}$ values. ${ }^{\circ}$ Challenge dose (in plaque-forming units (PFU) or tissue culture infectious dose yielding infection in $50 \%$ of wells $\left(\mathrm{TCID}_{50}\right)$ and route of challenge; only in reference 8 were both PFU and TCID ${ }_{50}$ given. IT = intratracheal; IN = intranasal; $\mathrm{OR}=$ oral; $\mathrm{OC}=$ ocular. $\mathrm{VP}=$ virus particles.

${ }^{d}$ Protection was measured as median log reductions in subgenomic RNA copies/ml (except for references 2 and 11 where viral RNA data are listed). The viral load (VL) data were derived from bronchoalveaolar lavages (BAL), intranasal swabs (INS), throat swabs (TS), oropharyngeal swabs (OPS) or anal swabs (AS), at times when VLs were approximately at their peak levels post-challenge. In some studies, more substantial protective effects could be detected after the peak values began to decline (see the primary papers for details). AM = arithmetic mean of the VL log values, which is equivalent to the GM (geometric means) of the antilog values.

e ND = not done (no data were presented in the paper).

${ }^{f}$ Since viral RNA declined without any discernable peak in the control animals, only RNA measurements for day 7 (the last time point sampled) are listed.

${ }^{8}$ Data are for the 2 dose (prime boost) group. 
h The macaques were challenged simultaneously via 4 different routes (IT-IN-OR-OC) with the various doses listed in the same order in the brackets. 
Table 4. Vaccine immunogenicity in human Phase 1 and/or Phase 2 trials

\begin{tabular}{|c|c|c|c|c|c|}
\hline /accine name (citation) & Design & Vaccine dose $\mathrm{e}^{\mathrm{a}}$ & Binding antibody titerb & NAb titer ${ }^{c}$ & T-cell response ${ }^{d}$ \\
\hline $\begin{array}{l}\text { Sinovac } \\
\text { SoronaVac (14) }\end{array}$ & Inactivated virus & $6 \mu g \times 2$ & GM titer 2500 & RV GM CPE titer $\sim 64$ & $\mathrm{ND}^{f}$ \\
\hline $\begin{array}{l}\text { Sinopharm/WIBP } \\
\text { Jnnamed, Phase 1 (15) }\end{array}$ & Inactivated virus & $\begin{array}{c}8 \mu \mathrm{g} \times 2 \\
\text { (day } 0 \text { and } 28 \text { ) }\end{array}$ & ND & RV GM titer 228.7 & ND \\
\hline $\begin{array}{l}\text { Sinopharm/WIBP } \\
\text { Jnnamed, Phase } 2 \text { (5) }\end{array}$ & Inactivated virus & $\begin{array}{c}8 \mu \mathrm{g} \times 2 \\
\text { (day } 0 \text { and } 21 \text { ) }\end{array}$ & ND & RV GM titer 282.7 & ND \\
\hline $\begin{array}{l}\text { Inopharm/WIBP } \\
\text { Jnnamed, Phase } 1 \text { (22) }\end{array}$ & Inactivated virus & $10 \mu g \times 3^{e}$ & GM EP (whole virus) 311 & RV GM ID50 297 & ND \\
\hline $\begin{array}{l}\text { Sinopharm/WIBP } \\
\text { Jnnamed, Phase } 2 \text { (22) }\end{array}$ & Inactivated virus & $5 \mu g \times 2$ & GM EP (whole virus) 215 & RV GM ID 50247 & ND \\
\hline $\begin{array}{l}\text { SanSinoBIO } \\
\text { d5-nCoV (23) }\end{array}$ & Ad5 virus & $1.5 \times 10^{11} \mathrm{VP} \times 1$ & GM titer 596.4 & $\begin{array}{c}\text { RV GM titer } 34 \\
\text { PV GM titer } 45.6\end{array}$ & $\begin{array}{l}\mathrm{GM} \sim 580 \\
(\text { day } 14)\end{array}$ \\
\hline $\begin{array}{l}\text { SanSinoBIO } \\
\text { Ad5-nCoV (24) }\end{array}$ & Ad5 virus & $1.0 \times 10^{11} \mathrm{VP} \times 1$ & GM titer (RBD) 656.5 & $\begin{array}{l}\text { RV GM titer } 19.5 \\
\text { PV GM titer } 61.4\end{array}$ & ND \\
\hline $\begin{array}{l}\text { straZeneca } \\
\text { hAdOx1 nCoV-19 (16) }\end{array}$ & ChAdeno virus & $5 \times 10^{10} \mathrm{VP} \times 1$ & Median EU 157.1 & $\begin{array}{l}\text { RV median ID }{ }_{50} 201 \\
\text { PV median ID50 } 87.9\end{array}$ & $\begin{array}{l}\text { Median } 856 \\
\text { (day 14) } \\
\text { Median 424 } \\
\text { (day 56) }\end{array}$ \\
\hline $\begin{array}{l}\text { straZeneca } \\
\text { hAdOx1 nCoV-19 (16) }\end{array}$ & ChAdeno virus & $5 \times 10^{10} V P \times 2$ & Median EU 997.5 & $\begin{array}{c}\text { RV median ID } 50372 \\
\text { PV median ID } \text { D }_{50} 450.9\end{array}$ & $\begin{array}{l}\text { Median 1642.3 } \\
\text { (day 14) } \\
\text { Median 528.7 } \\
\text { (day 35) } \\
\text { Median 614 } \\
\text { (day 56) }\end{array}$ \\
\hline $\begin{array}{l}\text { AstraZeneca } \\
\text { ChAdOx1 nCoV-19 (17) }\end{array}$ & ChAdeno virus & $3.5-6.5 \times 10^{10} \mathrm{VP} \times 2$ & $\begin{array}{c}\text { Median AU } \\
16,170-20,713\end{array}$ & $\begin{array}{l}\text { RV median ID } 80 \text { 144- } \\
193\end{array}$ & $\begin{array}{l}\text { Median 797-1187 } \\
\quad \text { (day 14) }\end{array}$ \\
\hline $\begin{array}{l}\text { lanssen } \\
\text { Ad26.COV2 (18) }\end{array}$ & Ad26 virus & $1 \times 10^{11} \mathrm{VP} \times 1$ & GM EU 695 & RV GM ID 50243 & $\begin{array}{c}\text { Median CD4+ } \\
\left.\sim 0.1 \% \%^{i} \text { day } 15\right) \\
\text { Median CD } 8+ \\
\sim 0.09 \% \text { (day } 15)\end{array}$ \\
\hline $\begin{array}{l}\text { oderna } \\
\text { RNA-1273 }(19,20)\end{array}$ & mRNA & $\begin{array}{l}250 \mu \mathrm{g} \times 2(17) \\
100 \mu \mathrm{g} \times 2(18)\end{array}$ & $\begin{array}{l}\text { GM EP } 1,262,975(17) \\
\sim 1000,000 \text { RBD (18) }\end{array}$ & $\begin{array}{l}\text { PV GM ID50 } \\
373.5(17) \\
\sim 300(18)\end{array}$ & $\begin{array}{l}\text { Median CD4+ } 800 \\
\text { Median CD8+ 40 (day } \\
\text { 43) (17) } \\
\text { Median CD4+ 1600 (day } \\
\text { 43) (18) }\end{array}$ \\
\hline $\begin{array}{l}\text { Pfizer/BioNTech } \\
\text { 3NT162b1 (25) }\end{array}$ & mRNA RBD & $30 \mu g \times 2$ & GM EU (RBD) 16,166 & RV GM ID 50267 & ND \\
\hline $\begin{array}{l}\text { Pfizer/BioNTech } \\
\text { 3NT162b1 (26) }\end{array}$ & mRNA RBD & $50 \mu g \times 2$ & GM EU (RBD) 25,006 & $\begin{array}{l}\text { RV GM ID } 50578 \\
\text { PV GM ID } 503100\end{array}$ & $\begin{array}{l}\text { CD4+ median } \sim 2000 \\
\text { CD8+ median } \sim 2600 \\
(\text { day } 29)\end{array}$ \\
\hline $\begin{array}{l}\text { Pfizer/BioNTech } \\
\text { 3NT162b1'g (27) }\end{array}$ & mRNA RBD & $30 \mu g \times 2$ & GM EU (S1) 6580-23,516 & RV GM ID50 101-267 & ND \\
\hline $\begin{array}{l}\text { Pfizer/BioNTech } \\
\text { 3NT162b2 g (27) }\end{array}$ & mRNA S-protein & $30 \mu g \times 2$ & GM EU (S1) 7895-9136 & RV GM ID50 149-361 & ND \\
\hline $\begin{array}{l}\text { Jovavax } \\
\text { JVX-CoV2373 (21) }\end{array}$ & S-Protein & $5 \mu g \times 2$ & GM EU 63,160 & RV GM ID>99 3906 & ND \\
\hline $\begin{array}{l}\text { Aamaleya Center } \\
\text { Gam-COVID-Vac }(28)^{\mathrm{h}}\end{array}$ & Ad26 + Ad5 virus & $1 \times 10^{11} \mathrm{VP}$ of each virus & GM EP (S1) 53,006 & RV GM CPE 6749.25 & $N A^{i}$ \\
\hline $\begin{array}{l}\text { MB, CAMS, PUMC } \\
\text { KMS-1 (29), Phase } 1\end{array}$ & $\begin{array}{l}\text { Inactivated virus } \\
\text { KMS-1 }\end{array}$ & $100-150$ unspecified units & GM titer 2000-4000 & RV GM CPE titer 20 & $\begin{array}{c}\text { AM } 250 \\
\text { (middle dose) } \\
\text { AM } 50 \\
\text { (high dose) }\end{array}$ \\
\hline $\begin{array}{l}\text { MB, CAMS, PUMC } \\
\text { KMS-1 (30), Phase } 2\end{array}$ & $\begin{array}{l}\text { Inactivated virus } \\
\text { KMS-1 }\end{array}$ & 150 unspecified high dose & GM EP 2432 & RV GM CPE titer 21.39 & ND \\
\hline
\end{tabular}


S-Protein virus-like particles

mRNA-S-protein
$3.75 \mu \mathrm{g} \times 2$

$12 \mu g \times 2$
GM ED50 300,000

Median EP 5463
PV GM ID $50 \sim 2200$

RV GM ID $50 \sim 630$

$\mathrm{RV}$ median $\mathrm{CPE}_{50} 113$
$\mathrm{GM} \sim 500$

ND

a The number of immunizations is also given. VP = viral particles.

${ }^{b}$ Antibody binding was measured against S-proteins (except when RBD, S1 protein, or inactivated, purified whole virus was used instead, as stated) in IgG ELISAs and the values are listed as ED50, endpoint (EP) or ELISA units derived from comparison with a standard curve (EU); AU = arbitrary units; titer = unspecified method of the titer determination. The samples were obtained at a time corresponding approximately to the peak response after the final (or only) immunization. GM = geometric mean. Tabulated values reported for (17) are the ranges of medians in the age groups 18-55, 56-69 and >=70 years taken together.

c Neutralization was quantified in PV or RV assays as indicated. The potency was measured as ID $D_{50}$, ID>99 or CPE 67 values 2 weeks after the final (or only) immunization, which corresponds approximately to the peak response. The values reported for references 15, 23 and 24 are given simply as GM titers, as in the original text where the cut-off was not defined.

d T-cell responses were measured in ELISPOT IFN-gamma assays and recorded as SFC/106 cells or intracellularly stained cells (in $\%$ measured by cytokine flow cytometry, CFC), which are PBMC except where subpopulations of CD4+ and CD8+ are indicated, after stimulation with different SARS-CoV-2 S-protein-derived peptides. The days between immunization (day 0) and sampling are also listed (in brackets).

e The binding antibody and NAb titer ranges were similar in the lower dose (2.5 and $5.0 \mu \mathrm{g})$ groups 14 days after the third dose. In other studies one dose stood out as giving stronger responses and was chosen for tabulation.

${ }^{\mathrm{f}} \mathrm{ND}=$ not done (no data were presented in the paper).

$\mathrm{g}$ The ranges listed for BNT162b1 and BNT162b2 are the GM values for the age groups 65-85 years (lower value) and 18-55 years (higher value).

h Data are for the frozen/thawed stock sub-component of the Phase 2 combination vaccine trial.

i IFN-gamma or IL-2 measured by intracellular cytokine staining (ICS).

i $\mathrm{NA}=$ not applicable (data were not presented in the relevant quantitative format; see text) 
Table 5. Comparisons of vaccine-induced antibody responses across different studies

Antibody binding assays (usually ELISAs), are performed as serum titrations or at only a single dilution.

Endpoint titers or $50 \%$ binding titers ( $E D_{50}$, effective serum dilution factor giving $50 \%$ of maximum binding) or units relative to standard curves or arbitrary units are reported.

NAbs are measured against either replicating viruses (RV assays) or S-protein pseudotyped viruses that do not complete an infection cycle (PV assays).

Usually PV assays are a few-fold more sensitive than RV assays and therefore generate higher titer values.

$\mathrm{NAb}$ data are reported as 50\% neutralizing titers ( $I \mathrm{D}_{50}$, inhibitory serum dilution factor giving $50 \%$ infectivity) or the more stringent neutralization $I_{80}$ or ID>99 values (see Fig. 3).

Instead of titers, areas under the curve (AUC) are sometimes measured.

In some primary papers, titers are listed in Tables, Figures or the text as multi-digit values. We repeat those numbers in this review, although using more than two significant figures is rarely justified.

When we have had to make estimates, the values we list in the text and Tables are preceded by an $\sim$ symbol.

We differentiate median and geometric or arithmetic mean (GM or AM)) values as was done in the primary papers. 


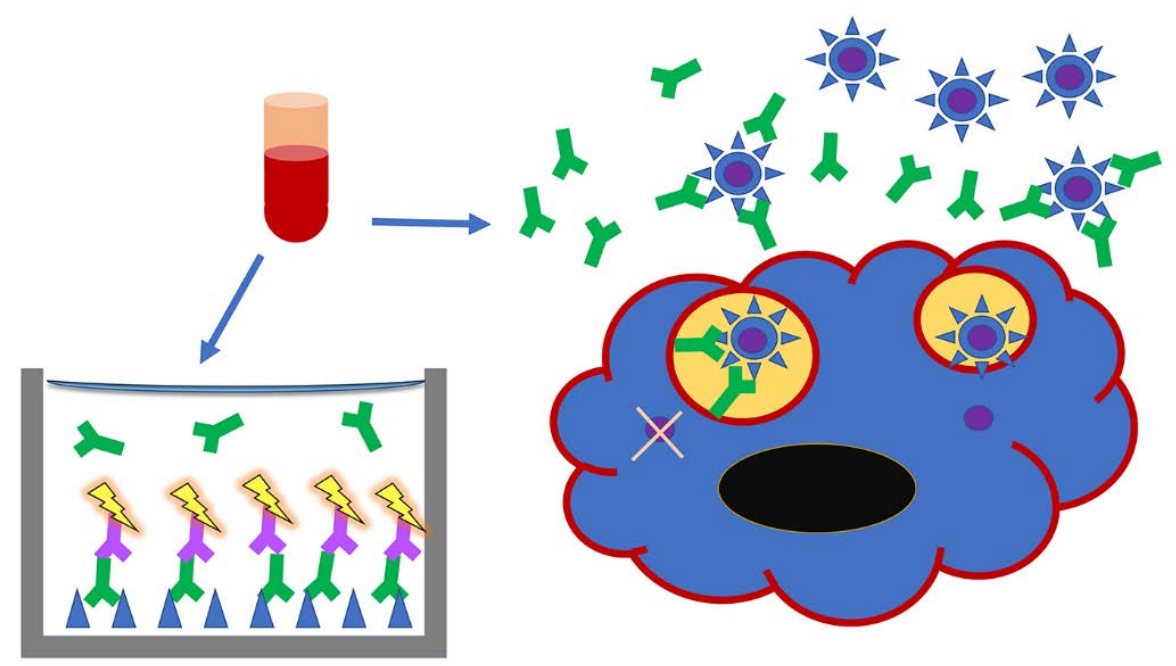

Fig. 1. The measurement of antibody binding and virus neutralization in vitro. Blood samples are obtained from patients or experimental animals and serum is separated. Serum antibody binding is usually measured by ELISA (left): S-proteins (blue triangles) or RBDs are immobilized in wells, S-specific antibodies (green) in titrated sera are allowed to bind and they are then detected with labeled anti-antibodies (purple with yellow flash) (51). Neutralization is measured as antibodymediated inhibition of viral infectivity in cell culture assays (right). A susceptible cell is shown with blue cytoplasm, black nucleus and red cell membrane. Pseudoviruses (PV) carry a signal gene but cannot form infectious progeny, whereas replicating viruses (RV) cause a cytopathicity $(51,52)$. Virus particles are shown as blue circles with triangular spikes, the latter representing the S-protein as in the ELISA. The internal viral core is purple. Antibodies in green bind to the S-protein on virions in suspension. Some extracellular virions are be prevented from receptor binding and cellular uptake by antibody binding to the Sprotein. Two virions are shown in endosomes. One has antibodies bound to the S-protein, which prevents fusion of the viral and endosomal membranes, thereby preventing entry of the viral core into the cytoplasm. 


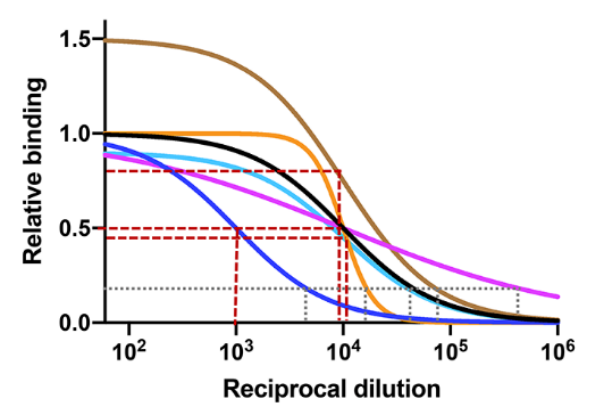

Fig. 2. Different kinds of binding titers. End-point titers and $E_{50}$ values are measured in ELISAs. Binding curves with different maxima, mid-points (or half-maximal values) and slopes (Hill coefficients, h) are depicted. Brown stippled lines show the derivation of $\mathrm{ED}_{50}$ at half the plateau values on the $\mathrm{y}$ axis values; grey stippled lines show the derivation of the endpoint titers, where the curve crosses a stipulated common cutoff value; all of these titer values are read on the $x$ axis. The $E D_{50}$ values are products of antibody concentration and affinity, the maxima reflect the number of antigenic epitopes and the slopes antibody heterogeneity and binding cooperativity.
A

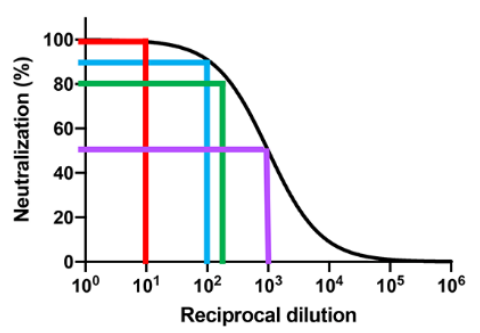

B

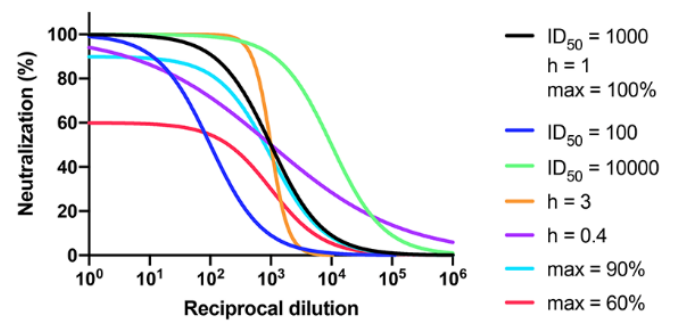

Fig. 3. The quantification of neutralization. A. Different degrees of inhibitory reciprocal dilutions are recorded for neutralization assays (purple $=I D_{50}$, green $=I D_{80}$, blue $=I D_{90}$ or red $=I D_{99}$ ). $B$. Neutralization curves differ not only in mid-points $\left(I_{50}\right)$ but in plateau of maximum neutralization (max \%) and slope (Hill coefficient, h) $(51,52,56)$. Token values for these three quantities are given for the black curve; one quantity at the time is varied for the other curves as indicated by the color code. Drastically different curves can therefore generate similar AUC values. The relationship between antibody binding to surface viral proteins and neutralization depends on binding strength (affinity), concentration, and the occupancy of NAb on the virion that is required for neutralization (52). What neutralizing titers are sufficient for protecting organisms from infection depends on viral dose and other factors and tends to fall in the range ID $D_{50} 100-1000(34,51,52,56)$. When $\mathrm{h}=1$, the $I D_{99}$ value is $\sim 100 I_{50}$. Vaccine-mediated protection in vivo is dominated by neutralization for many viruses, but can also be influenced by non-NAb antiviral effects and cytotoxic T-cell responses, as well as by innate immunity and other host factors. 